\title{
Corpus
}

Dialectologie : corpus, atlas, analyses

\section{Testing linguistic theory and variation to their limits: The case of Romance}

\section{Adam Ledgeway}

\section{OpenEdition}

1 Journals

\section{Electronic version}

URL: http://journals.openedition.org/corpus/2408

DOI: $10.4000 /$ corpus. 2408

ISSN: $1765-3126$

\section{Publisher}

Bases; corpus et langage - UMR 6039

\section{Printed version}

Date of publication: 1 January 2013

Number of pages: 271-327

ISSN: 1638-9808

\section{Electronic reference}

Adam Ledgeway, «Testing linguistic theory and variation to their limits: The case of Romance »,

Corpus [Online], 12 | 2013, Online since 14 May 2014, connection on 08 September 2020. URL : http:// journals.openedition.org/corpus/2408; DOI : https://doi.org/10.4000/corpus.2408 


\title{
Testing linguistic theory and variation to their limits: The case of Romance
}

\author{
Adam LEDGEWAY \\ University of Cambridge
}

Drawing on a number of corpus studies, including a considerable amount of data taken from my own corpora of textual and fieldwork studies on the dialects of Italy, I shall explore, in a manner which is accessible to both general scholars of the Romance languages and linguists, how the richly documented diachronic and synchronic variation exhibited by the Romance languages, and especially their dialectal varieties, offers an unparalleled wealth of linguistic data (often of a typologically exotic nature) of interest not just to Romance linguists, but also to general linguists. This perennially fertile and still under-utilized testing ground, I will show, has a central role to play in challenging linguistic orthodoxies and shaping and informing new ideas and perspectives about language change, structure and variation, and should therefore be at the forefront of linguistic research and accessible to the wider linguistic community. At the same time, a familiarity with current key ideas and assumptions in theoretical linguistics has an important role to play in understanding the structures and patterns of Romance, and, in particular, those known to us only through the texts of earlier periods where native speakers are not available to provide crucial grammaticality judgments and fill in the missing empirical pieces of the relevant puzzle.

Following a brief introduction in $\S 1$ to linguistic variation across Romance in relation to parameters, universals and language typology, I shall then explore in $\$ 2$ some case studies of microvariation across Romance which highlight what Romance can do for syntactic theory by way of testing, challenging and expanding our theory of language and the empirical base. By the same token, the tools and insights of current theories of 


\section{A. LEDGEWAY}

syntax can also be profitably used to throw light on many of the otherwise apparently inexplicable facts of Romance microvariation, the topic of the $\$ 3$ where I shall highlight what syntactic theory can do for Romance through the exploration of a number of Romance case studies which have traditionally proven, at the very least, extremely difficult to interpret in a unitary and satisfactory fashion.

\section{Linguistic variation}

\subsection{Parameters}

One of the areas in which research into Romance has proven particularly influential is the investigation of linguistic parameters, those dimensions of linguistic variation along which natural languages are said to vary. To cite just one simple example, in his Issues in Italian Syntax, Rizzi (1982) observed that whereas in languages like English it is impossible to move a relative pronoun like to whom in (1a) from the embedded indirect question which lies they told ... to the next clause up, such movement is possible in the corresponding Italian example (1b), where a cui successfully raises out of the embedded clause headed by che bugie. ${ }^{1}$

[1] a *your brother, [CP to whom [IP I wonder [CP which lies [IP they told whom] ] (Eng.)

b tuo fratello, [СP a cui [IP mi domando [CP che bugie [IP abbiano raccontato $a$ eui]]]] (It.)

1 The abbreviations for languages and localities cited in the following discussion are: Abr. (Abruzzese), Arl. (Ariellese, eastern Abruzzo), Bal. Cat. (Balearic Catalan), Cal. (Calabrian), Cat. (Catalan), Cic. (Cicagnino, Liguria), Cos. (Cosentino, northern Calabria), Crs. (Corsican), Ctz. (Catanzarese, central Calabria), Dmc. Sp. (Dominican Spanish), Eng. (English), Erv. (Ervedosa do Douro, north-eastern Portugal), Fr. (French), Ger. (German), Glc. (Galician), Gsc. (Gascon), It. (Italian), Leo. (Leonese), Lgd. (Lengadocien), Lul. (Lulese, Nuoro, Sardinia), Mes. (Messinese, north-eastern Sicily), Nap. (Neapolitan), Occ. (Occitan), Pal. (Palermitano), Pgl. (Pugliese), Pv. de At. (Póvoa de Atalaia, central-eastern Portugal), Rip. (Ripano, south-eastern Marches), Ro. (Romanian), Sal. (Salentino, southern Puglia), Sic. (Sicilian), Sp. (Spanish), Srd. (Sardinian), Tsc. (Tuscan), Umb. (Umbrian), Wal. (Walloon, southern Belgium). 
Testing linguistic theory and variation to their limits

Rizzi's solution, subsequently widely adopted, was to propose that the difference between English and Italian observable in (1) is a consequence of a different parametric setting on the boundaries for movement in natural languages (viz. subjacency): in English inflected verb phrases (IPs) constitute boundaries for movement, of which a maximum of only one can be crossed in any one derivation, whereas in Italian complementizer phrases (CPs) count as boundaries for movement, of which again only one can at most be crossed. Therefore, the ungrammaticality of (1a) follows because the phrase to whom illicitly moves over two boundaries, namely I wonder and they told, whereas (1b) is grammatical because the relative a cui crosses only one boundary, the $\mathrm{CP}$ introduced by che bugie.

In more recent years the significance of Romance dialects for the generative enterprise has also been increasingly recognized, inasmuch as they offer fertile, and often virgin, territory in which to profitably study parametric variation. While neighbouring dialects tend to be closely related to each other, manifestly displaying in most cases a high degree of structural homogeneity, they do nonetheless often diverge minimally in significant ways which allow the linguist to isolate and observe what lies behind surface differences in particular parametric settings across a range of otherwise highly homogenized grammars. By drawing on such microvariation, it is possible to determine which phenomena are correlated with particular parametric options and how such relationships are mapped onto the syntax. A clear example of such reasoning comes from the socalled dative shift construction, a phenomenon attested in a number of Germanic languages whereby an underlying indirect object, such as to Mary in (2a), can be reanalyzed and promoted to direct object, where Mary now comes to precede the old direct object $a$ book. Furthermore, it has been claimed that the possibility of dative shift is linked to another structural property, that of stranding prepositions in $w h$-questions and relative clauses, as demonstrated in (2b)

[2] a John gave a book [to Mary] / [Mary] a book

b [Who] did John give a book [pP to [DP Whe] ? 


\section{A. LEDGEWAY}

In contrast, it is claimed that Romance languages do not display either dative shift or preposition stranding (Kayne 1984; Larson 1988: 378; Demonte 1995: 8), as the sharp ungrammaticality of the Italian examples in (3) demonstrates:

[3] a Ugo diede un libro [a Maria]/*[Maria] un libro (It.) Ugo gave a book to Maria / Maria a book $\mathrm{b} *$ [Chi] diede Ugo un libro [PP $\mathbf{a}$ [DP ehi]] ? (It.)

Who gave Ugo a book to

This apparent Germanic vs Romance parametric variation is complicated by the fact that something very similar, if not identical to dative shift, is found in many southern Italian dialects (Sornicola 1997: 35-36; Ledgeway 2000: 46-52; 2009a: 844-847), witness the representative Neapolitan and Cosentino examples in (4):

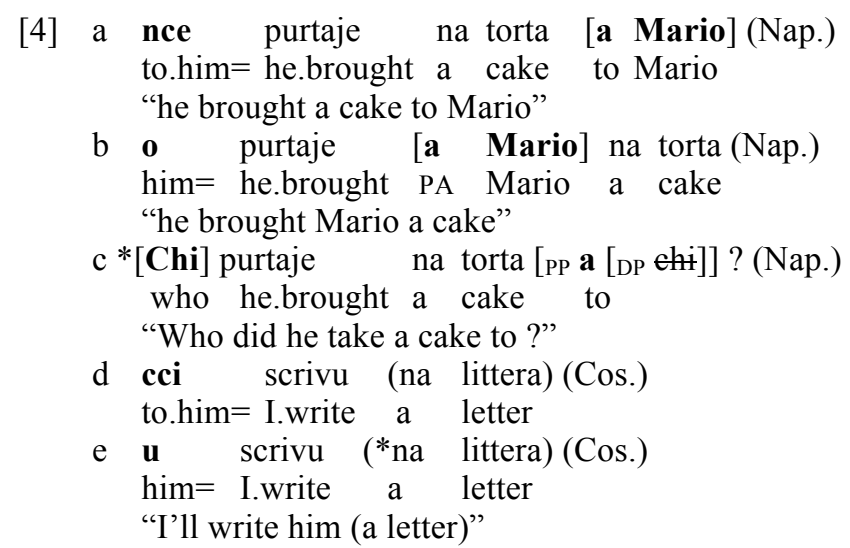

Beginning with the Neapolitan example (4b), we see that the RECIPIENT argument a Mario, the underlying indirect object in (4a), has been advanced to direct object and is now marked by the prepositional accusative (PA), as shown by its position in front of the old direct object $n a$ torta and by the fact that $a$ Mario is now referenced by an accusative clitic pronoun $o$ "him", and not the third person dative pronoun nce in (4a). Other neighbouring southern dialects such as Cosentino, by contrast, exhibit a more constrained type of dative shift, inasmuch as RECIPIENT arguments (cf. dative clitic $c c i$ "to him" in 
Testing linguistic theory and variation to their limits

(4d)) may only surface as direct objects (cf. accusative clitic $u$ "him" in (4e)) in monotransitive clauses.

These Italian dialects reveal therefore three important things. Firstly, dative shift is not a Germanic vs Romance parametric option. Secondly, the supposed link between dative shift and preposition stranding, argued to be derivable from a single parametric option, does not hold, the presence of both phenomena in languages like English simply representing a fortuitous combination rather than the principled outcome of a particular parameter setting, since preposition stranding is not found in these same southern dialects (cf. 4c). Thirdly, it is incorrect to subsume all instances of accusative marking of RECIPIENT arguments under the generic heading of dative shift, since some of the dialects of southern Italy prove sensitive to the mono- vs ditransitive distinction (cf. 4e). It follows therefore that what might otherwise be taken to represent the surface reflexes of a single parametric setting, in dialects like Neapolitan, namely the accusative marking of all RECIPIENT arguments irrespective of whether they occur in mono- or ditransitive clauses, turns out in fact to conceal two distinct structural operations in the light of evidence gleaned from dialects such as Cosentino.

\subsection{Language universals}

Romance varieties also have much to contribute in the area of so-called universal principles of language, essentially a system of rules forming part of the genetic endowment known as Universal Grammar which are believed to hold of all human languages. A good illustration of the valuable role that Romance can play in testing linguistic universals concerns the licensing of nominative Case. Within current theory, it is assumed that Infl, the locus of verbal inflection, may be specified as [+tense] or [-tense], featural specifications which in turn are argued to correlate respectively with the verb's ability or otherwise to license a nominative Case-marked subject. This [ \pm tense] distinction is supported by the evidence of many of the world's languages, including French where tensed verbs license nominative subjects (5a), but untensed verbs such as infinitives and gerunds only allow null (Caseless) PRO subjects (5b): 


\section{A. LEDGEWAY}

[5] a Elle rentre à la maison $($ Fr. $)$ she returns to the home "She returns home"

b Avant de $\boldsymbol{\emptyset}_{\mathrm{i}} /$ *elle rentrer, $\mathrm{Jean}_{\mathrm{i}}$ a téléphoné (Fr.) before of $\boldsymbol{\emptyset}_{\mathrm{i}}$ she to.return Jean has telephoned "Before going home, Jean rang"

Yet, the evidence of Romance dialects reveals that the supposed universal correlation between the specification of Infl and the availability of nominative Case is entirely spurious (Ledgeway 1998; 2000: ch. 4; Mensching 2000). ${ }^{14}$ In particular, dialects from the length and breadth of the Romance-speaking world demonstrate an abundant use of overt nominative subjects in conjunction with infinitival verbs:

[6] a Cantar nosaltres ara no seria mala idea (Cat.) to.sing we now notwould.be bad idea

"It wouldn't be a bad idea for us to sing now"

b Ieu trabalha per elo s' amusa (Lgd.) I work for she self $=$ to.amuse

"I work so that he can enjoy himself"

c nu sèrve egnî u vìgile! (Cic.) not it.serves to.come the traffic.warden "There's no need for the traffic warden to come"

d Înainte de a veni ea a bătut un vânt puternic (Ro.) before of to to.come she has beaten a wind terrible "Before she came, there was a terrible wind"

e non keljo a vénnere tue (Lul.) not I.want to to.come you "I don't want you to come"

\subsection{Typological variation}

Data like those exemplified in (6) also illustrate how investigations of Romance dialects frequently reveal that the extent of typological variation within Romance, and indeed even within Indo-European, can in particular cases prove to be considerably greater than is traditionally assumed. In this respect, one only has to think of such examples as the Romance inflected infinitives, gerunds and participles illustrated in Tables 1 and 2 with representative examples in $(7)^{2}$, which, as intermediate cate- 
gories, clearly throw into turmoil traditionally narrow interpretations of finiteness in terms of a binary finite vs non-finite dichotomy (cf. Ledgeway 2007c):

Table 1. Romance inflected infinitives (cant- "sing")

\begin{tabular}{|l|l|l|l|l|l|l|l|}
\hline & Infinitive & $1 \mathrm{sg}$ & $2 \mathrm{sg}$ & $3 \mathrm{sg}$ & $1 \mathrm{pl}$ & $2 \mathrm{pl}$ & $3 \mathrm{pl}$ \\
\hline Glc. & cantar & $-\varnothing$ & $-e s$ & $-\varnothing$ & $-m o s$ & $-d e s$ & $-e n$ \\
\hline OLeo. & cantar & $-\varnothing$ & $-e s$ & $-\varnothing$ & $-m o s$ & $-d e s$ & $-e n$ \\
\hline ONap. & cantar $(e)$ & $-\varnothing$ & $-\varnothing$ & $-\varnothing$ & $-m o$ & $-v o$ & $-n o$ \\
\hline (E)Pt. & cantar & $-\varnothing$ & $-e s$ & $-\varnothing$ & $-m o s$ & $-d e s$ & $-e m$ \\
\hline Srd. & cantare & $-p o$ & $-s$ & $-t$ & $-m u s$ & $-d z i s$ & $-n$ \\
\hline
\end{tabular}

Table 2. Romance inflected gerunds \& participles (cant- "sing")

\begin{tabular}{|c|c|c|c|c|c|}
\hline & \multicolumn{3}{|c|}{ Gerund } & Present/Past Participles \\
\hline & Glc. & Pv. de At. & \multicolumn{3}{c|}{ ONap. } \\
\hline & cantando & cantand(o) & cantanno & cantante & cantato \\
\hline $1 \mathrm{sg}$ & $-\varnothing$ & $-\varnothing$ & $-\varnothing$ & $-\varnothing$ & $-\varnothing$ \\
\hline $2 \mathrm{sg}$ & $-\varnothing$ & $-s$ & $-\varnothing$ & $-\varnothing$ & $-\varnothing$ \\
\hline $3 \mathrm{sg}$ & $-\varnothing$ & $-\varnothing$ & $-\varnothing$ & $-\varnothing$ & $-\varnothing$ \\
\hline $1 \mathrm{pl}$ & $-m o s$ & $-m o s$ & $-m o$ & - & - \\
\hline $2 \mathrm{pl}$ & $-d e s$ & $-e i s$ & $-v o(-v e)$ & - & - \\
\hline $3 \mathrm{pl}$ & - & $-e m$ & $-n o(-n e)$ & $-n o$ & $-n o$ \\
\hline
\end{tabular}

[7] a é doado supoñeren as cousas (Glc.) it.is easy to.suppose. $3 \mathrm{pl}$ the things "it is easy for them to assume things"

b não saíndomos de casa, morrâmos à fome (Erv.) not leaving.1pl of home we.die at.the hunger "if we don't leave the house, we'll starve to death"

c datonosse insembla salute como convenne (ONap.) given. $3 \mathrm{pl}=$ self together greeting as required "after having greeted one another as was customary"

Another acute example comes from the unique infectious development of inflection in the Marchigiano dialect of Ripatransone. ${ }^{3}$ Simplifying somewhat, in addition to the usual person/ number agreement, the Ripano finite verb simultaneously displays

(1998: 41-46; 2000: 109-114; 2009a: 585-590), Mensching (2000), Lobo (2001).

3 See Parrino (1967), Lüdtke (1974; 1976), Mancini (1993), Harder (1998), Ledgeway (2004b; 2012a: §6.3.4), D’Alessandro (2011). 


\section{A. LEDGEWAY}

masculine/feminine gender agreement with the subject, not to mention the possibility of agreement with a so-called third person neuter subject, by means of final inflectional vowel contrasts which, to all appearances, seem to have been grafted onto the verbal paradigm from the nominal paradigm. By way of example, we illustrate below in Table 3 the nominal paradigm for fijj"son, daughter" and prafutta "ham" together with the present tense paradigm of the verb magnà "to eat" and piovara "to rain":

Table 3. Ripano nominal \& present indicative paradigms

\begin{tabular}{|c|c|c|c|c|c|c|c|}
\hline & Masc. & Fem. & Neut. & Pers. & Masc. & Fem. & Neut. \\
\hline \multirow{3}{*}{$\mathrm{Sg}$. } & \multirow{3}{*}{ fijju } & \multirow{3}{*}{ fijje } & \multirow{3}{*}{ prafutto } & $1 \mathrm{sg}$ & \multirow{3}{*}{ magnu } & \multirow{3}{*}{ magne } & \\
\hline & & & & $2 \mathrm{sg}$ & & & \\
\hline & & & & $3 \mathrm{sg}$ & & & piovo \\
\hline \multirow{3}{*}{ P1. } & \multirow{3}{*}{ fijji } & \multirow{3}{*}{ fijja } & & $1 \mathrm{pl}$ & magnemi & magnema & \\
\hline & & & & $2 \mathrm{pl}$ & magneti & magneta & \\
\hline & & & & $3 \mathrm{pl}$ & magni & magna & \\
\hline
\end{tabular}

Far from being limited to finite verbs, such a rich and complex system of agreement has come to permeate even non-finite verb forms such as past participles (8a), gerunds (8b) and infinitives (8c), not to mention other parts of speech including predicative nominal complements of the copula avé "to have" (9a), whinterrogatives (9b) and quite remarkably, on a par with such languages as Welsh, prepositions $(9 \mathrm{c})$ :

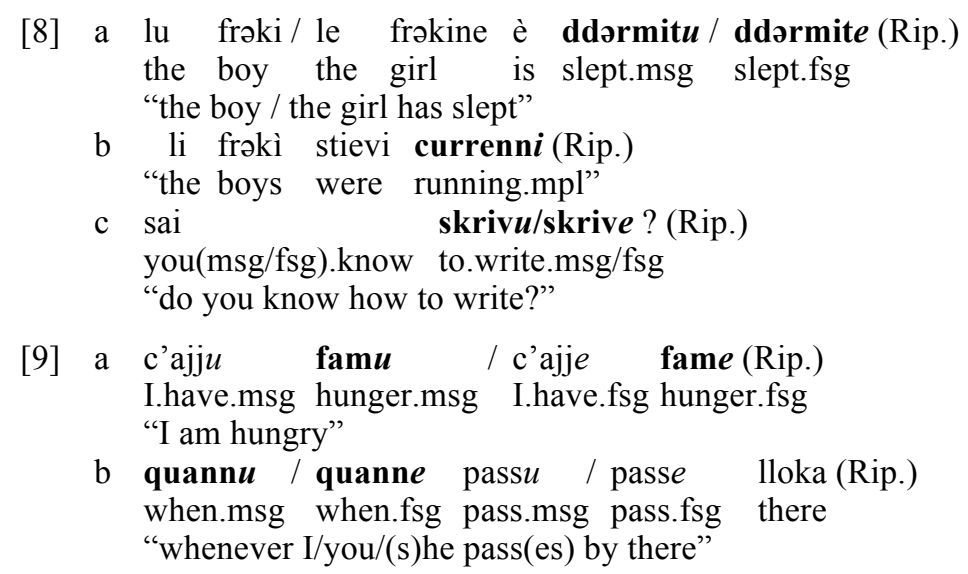


Testing linguistic theory and variation to their limits

c dopu lu ddi / dope le notte (Rip.)

after.msg the.msg day.m after.fsg the.fsg night.f

"following the day / night"

\subsection{Interim conclusions}

From the preceding introductory discussion, it is clear that the wealth of Romance standard and especially dialectal data, although frequently overlooked in the past, have a great deal to contribute to research into such areas as parametric variation, linguistic universals and typological variation. Nonetheless, the syntax of the dialects still represents a relatively poorly understood area of Romance linguistics, to the extent that there still remains a considerable amount of fieldwork to be done in recording and cataloguing the linguistic diversity within the Romània, as well as in bringing such facts to the attention of the wider linguistic community. With this in mind, in what follows we shall offer a number of valuable insights into the littlestudied syntax of the Romance dialects in an attempt to highlight their significance for issues in general linguistic theory and their potential as relatively unexplored experimental territory in which to investigate new ideas about language structure, change and variation. Keeping the technical detail to a minimum, we shall discuss a number of issues relating to the syntax of Romance under the two broad headings of what Romance can do for syntactic theory and what syntactic theory can do for Romance. Under the former heading we shall review a number of assumptions about language structure and variation that have been proposed in the literature, demonstrating how in the specific cases examined the Romance dialect data contradict such principles and parameters, rendering them either invalid or in need of further elaboration. Under the latter heading, by contrast, we shall bring to light some of the less familiar and more problematic aspects of Romance syntax which can be shown to find an enlightening interpretation in light of current theoretical assumptions. 


\section{A. LEDGEWAY}

\section{What Romance can do for syntactic theory}

\subsection{Pro-drop parameter}

Undoubtedly, one of the best known and most widely studied parameters is the so-called pro-drop (or null subject) parameter (for a recent overview, see Biberauer, Holmberg, Roberts and Sheehan 2009). Limiting our attention to Romance and Germanic, it is traditionally claimed that, with the exception of modern French, morphological Agr(eement) for person and number on the Romance verb is sufficiently rich to license a null subject (11a), whereas in such languages as English Agr is so impoverished that that it is unable to recover the identity of a null pronominal subject which must instead be phonologically expressed (10a). By the same token, it is also assumed (cf. Chomsky 1981: 28; Rizzi 1986: 410; Haider 2001: 285) that expletive (or nonreferential) pronouns are null in the former (11b) but overt in the latter $(10 \mathrm{~b}){ }^{4}$

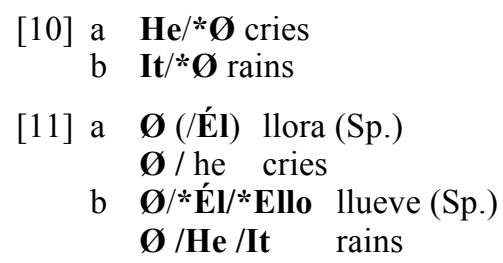

On a par with others, Rizzi (1982: 143ff.) derives this supposed universal distinction from the pro-drop parameter, which he argues yields the four language types illustrated in Table 4:

Table 4. Typology of null subjects

\begin{tabular}{|l|c|c|c|c|}
\hline Pronoun & $\begin{array}{c}\text { Type 1 } \\
\text { English }\end{array}$ & $\begin{array}{c}\text { Type 2 } \\
\text { Spanish }\end{array}$ & $\begin{array}{c}\text { Type 3 } \\
\text { German }\end{array}$ & $\begin{array}{c}\text { Type 4 } \\
?\end{array}$ \\
\hline Null referential & - & + & - & + \\
\hline Null expletive & - & + & + & - \\
\hline
\end{tabular}

Language types 1 and 2 are exemplified by English and Spanish, respectively. In Spanish both null expletives and null referential pronouns are licensed, whereas in English both types

4 On the status and distribution of expletive subject clitics, see Oliviéri (2009) and Kaiser, Oliviéri and Palasis (in press). 
of null pronoun are excluded. Type 3 is argued to characterize German where, in contrast to referential pronouns which are invariably overt (12a), overt expletive pronouns are only licensed when they occur in clause-initial position (12b):

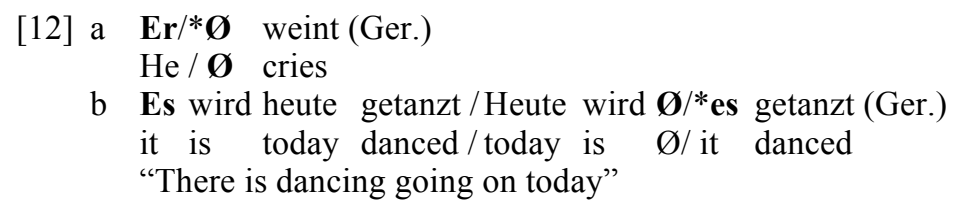

On the other hand, Rizzi (1982: 143) explicitly argues that type 4 languages with overt expletive subjects but null referential subjects are "excluded for intrinsic reasons". However, the evidence of a number of non-standard Romance varieties demonstrates that type 4 languages do indeed exist. For example, although Neapolitan is a pro-drop language (13a), it also displays structures such as those in (13b) where the subject position is filled by the overt expletive chello "that" (Sornicola 1996; Ledgeway 2009a: 290-294; 2010), a pattern replicated by a number of other Romance varieties (14a-e).

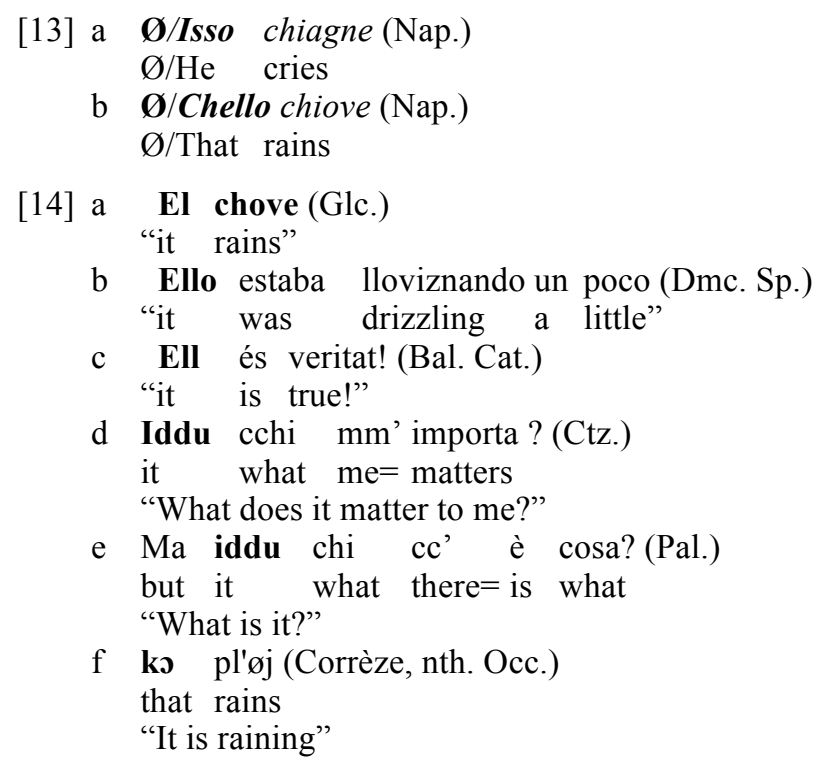

With the exception of the northern Occitan example in (16f), for which see Kaiser, Oliviéri and Palasis (in press), in most cases 


\section{A. LEDGEWAY}

the use of the overt expletive in such examples is associated with specific pragmatic functions (Sornicola 1996: 325-326; Ledgeway 2003; 2009a: 290-291; Hinzelin 2009), typically marking the illocutionary force of the clause as exclamative (cf. 14c) or interrogative (often with rhetorical overtones; cf. 14de), a usage which still requires much more detailed investigation. Summing up, the data considered here lead us to conclude, with Kaiser, Oliviéri and Palasis (in press), that the ability to drop referential pronouns and the availability of overt expletives are not necessarily mutually exclusive or, for that matter, two interrelated properties of a single pro-drop parameter. At the same time, however, the overt expletives of most of these Romance dialects cannot be equated tout court with those of languages like English and French in view of the marked pragmatic functions of the former and the purely syntactic nature of the latter.

The wealth and extent of the Romance evidence is such that our typology of null subjects does not, however, stop here. Turning our attention to medieval Romance, it has long been noted (Adams 1987; Roberts 1993: §3.2; Benincà 1994; 2006; 2010: §3.2.1; Salvi 2004: 16f., 26-31; Ledgeway 2012a: 74-75) that these varieties display an asymmetric distribution of null subjects, a pattern more robustly represented in Gallo-Romance (French, Occitan, and northern Italian dialects) than either in Ibero-Romance or central-southern Italo-Romance (Salvi 2004: 30f.). In particular, whereas in root clauses null subjects are freely licensed $(15 \mathrm{a}-\mathrm{c})$, in subordinate clauses pronominal subjects must usually be phonologically expressed (16a-c), although not interpreted as emphatic or contrastively-focused. Illustrative in this respect is the old Umbro-Tuscan example in (16c), where, despite the coreference of main and embedded clause subjects, the latter is overtly realized yielding a structure which would be judged ungrammatical, for example, in modern Italian where the presence of an overt pronoun in the same context would typically signal switch reference.

[15] a Si Ø errent tant en tele maniere qu' [...] (OFr.) so (they) wander so.much in such way that "they thus wandered so much in such a way that $[\ldots]$ " 
Testing linguistic theory and variation to their limits

b Del cor $\boldsymbol{\varnothing}$ sospir e dels olhs $\varnothing$ plor (OOcc.) of.the heart (I) sign and of.the eyes (I) cry "I sigh from the heart and cry from the eyes"

c manifestamente $\varnothing$ l'hoe vedutonelle cose [...] (OTsc.) manifestly (I) it=have seen in.the things "I have seen this clearly in those things $[\ldots]$ "

[16] a Endementiers que il regadoient les letres et la while that they looked.at the letters and the damoisele, que il plagnoient sa mescheance (OFr.) young.lady that they regretted her misfortune "While [that] they looked at the letters and the young lady, [and that] they regretted her misfortune"

b Non es meravelha s' eu chan/Melhs de nul autre not is wonder if I sing better of no other chantador (OOcc.)

singer

"It is no wonder if I am a better singer than all others"

c Elli conosce certamente ch' elli avea ucciso lo migliore he knows certainly that he had killed the best cavaliere del mondo (OUmb.-Tsc.) knight of.the world "He certainly knows that he had killed the best knight in the land"

This asymmetrical distribution leads us to conclude that null subjects in medieval Romance were not licensed exclusively, if at all, by rich verb inflection for person and number, insofar as verbal Agr is equally rich in both root and subordinated clauses, but by a structural property (to be discussed below in §3.2) which aligns the verb with distinct positions in both clause types. Indeed, the unreliability of verb morphology as a diagnostic for correctly predicting the distribution of null subjects is further evidenced by Ripano, a pro-drop variety, whose verb was seen in Table 3 above, witness the three singular persons of the paradigm (namely. magnu (m.) vs magne (f.)), to privilege the marking of gender over that of person, despite traditional claims that the licensing of null subjects is directly linked to the overt marking of the person feature.

In summary, the null pronominal types seen in medieval Romance and Ripano cannot be readily accommodated in terms of currents theories of a binary null subject parameter (cf. also Oliviéri 2009; Kaiser, Oliviéri and Palasis in press) and, in 


\section{A. LEDGEWAY}

particular, the typology of null subjects predicted by such models as that observed in Table 4 above which ultimately reduce tout court the distribution of null pronominals to the availability of rich morphological Agr for person on the finite verb.

\subsection{Verb positions}

The confines of the verbal domain are generally taken to extend beyond the immediate $v$-VP shell, where the external and internal arguments are first-merged, to include a dedicated structural position Infl(ection) (Chomsky 1981; 1986) > T(ense) (Chomsky 1995). The latter represents the locus of verbal inflection and licenses the external argument's Case and phi-features with which it enters into a Spec-head configuration upon raising of the subject to its associated specifier position (SpecIP $>$ SpecTP). Not only can this head position be lexicalized by distinct auxiliaries (cf. epistemic use of Catalan auxiliary deure "must" to express supposition in (17a)) but, in the absence of the latter, may be overtly filled by the raised lexical verb where its finite inflectional features can be licensed (cf. epistemic use of the future in substandard Catalan to express supposition in (17b); see Badia I Margarit 1962, I: 391).

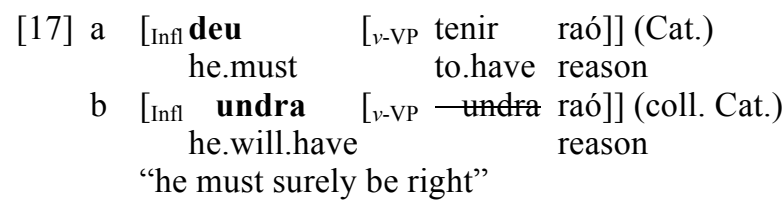

These structural assumptions provide a natural way of interpreting the observed contrast in the (unmarked) position of the finite verb in languages like English (18a) on the one hand and French (18b) on the other:

[18] a John [Infl Ø [v-VP often skis]] (Eng.)

b Jean [Infl skie [ $v$-VP souvent skie] (Fr.)

Exploiting the fixed positions of VP-adverbs like "always" as a diagnostic indicator of the left edge of the $v$-VP complex, we can now straightforwardly distinguish between overt verb-raising languages like French, where the finite verb raises to the Infl position to the left of VP-adverbs, and languages like English, where the verb remains in situ to the right of such VP-adverbs 
Testing linguistic theory and variation to their limits

and the Infl position is not overtly lexicalized in the syntax, a difference traditionally retraced to the respective richness of verbal inflection in the two languages (Emonds 1978; Pollock 1989; Belletti 1990).

Nonetheless, recent research has revealed a much more nuanced interpretation of Romance verb movement than these familiar broad-brush treatments which classify Romance tout court as having overt verb movement. Following the seminal work of Cinque (1999), Infl is now commonly interpreted as a general label for the rich inflectional area of the clause (the I-domain) made up of a series of distinct functional projections dedicated to marking various temporal, aspectual, modal and voice distinctions ranging over the lexical verb, its arguments, and possible adjuncts which can also be identified by the semantically corresponding adverbial modifiers they host (cf. also Cinque 2002; 2006; Belletti 2004; Rizzi 2004). Armed with these assumptions about a universal fixed hierarchy of adverb positions and corresponding functional projections, we can now construct a fine-grained typology of Romance varieties along the lines of (19):

$$
\begin{aligned}
& \text { 19] a } \quad \operatorname{Asp}_{\text {Habit. }} \quad \text { Asp }_{\text {Cont. }} \operatorname{Asp}_{\text {Compl.[vp...] }} \\
& \begin{array}{llll}
\text { a normalmente } & \underline{\text { todavía veo todo veo (Sp.) }} \text { vedo } \underline{\text { ancora }} \text { vedo tutto } & \text { vedo (It.) }
\end{array} \\
& \text { c je vois d'habitude vois encore vois tout vois (Fr.) } \\
& \text { I see usually see still see all } \\
& \text { "I can usually still see everything" }
\end{aligned}
$$

Although in all three varieties exemplified in (19) the finite lexical verb invariably leaves its base position to vacate the verb phrase, witness its position to the left of the completive adverb "everything" immediately adjacent to the VP, it raises to different functional projections within the I-domain as illustrated by its differential position with respect to different adverb classes. For example, in Spanish (19a) the finite verb raises to the head position of the continuative aspectual projection immediately below the adverb "still", whereas in Italian (19b) it appears to raise slightly higher to the head position of the habitual aspectual projection below the adverb "usually", and in French (19c) it raises to the highest available position above all adverb classes. 


\section{A. LEDGEWAY}

On the basis of evidence like this, let us assume that the various adverbs and their associated functional projections making up the inflectional core of the clause can be broadly divided into two "spaces" termed the Lower Adverb Space (LAS) and the Higher Adverb Space (HAS). Broadly speaking, the HAS comprises modal functional projections variously spelt out by speaker-oriented adverbs marking such categories as evidential (e.g. "apparently"), epistemic (e.g. "presumably") and irrealis (e.g. "perhaps") modality, whereas the LAS principally includes aspectual functional projections lexicalized by adverbial classes including perfective (e.g. "always") and continuative (e.g. "still") aspects, with temporal projections and associated adverbs (e.g. $\mathrm{T}_{\text {Past }^{-}}$"then", $\mathrm{T}_{\text {Anterior }}$ "already") variously scattered across both spaces. Assuming in this way the clause to consist of a highly articulated functional structure, we can interpret a number of surface differences across Romance in terms of the varying extent of verb movement around different adverb classes in these two adverbial spaces, as illustrated in (20a-e):

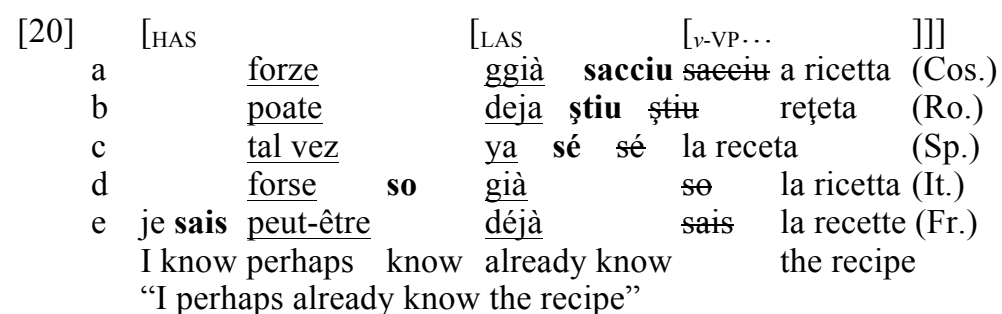

It can be seen that whereas in French (20e) the finite lexical verb raises to the highest position within the HAS (Rowlett 2007: 106f.), in Calabrian (20a), Romanian (20b) and Spanish (20c) they typically raise only as far as the LAS. ${ }^{5}$ Italian (20d) represents an intermediate case insofar as the finite lexical verb targets a clause-medial position sandwiched between the HAS and the LAS (Cinque 1999: 31, 110f., 180 fn. 80; Ledgeway and Lombardi 2005: 87f.).

5 Lois (1989), Cinque (1999: 152), Ledgeway and Lombardi (2005: 86-89, 102 n. 12), Monachesi (2005: 178), D’Alessandro (2010: 35f.), Ledgeway (2012a: §4.3.2). 
Testing linguistic theory and variation to their limits

These same assumptions about the fixed positions of adverbs also allow us to plot the differential position of non-finite verbs such as the active participle in the following examples: ${ }^{6}$

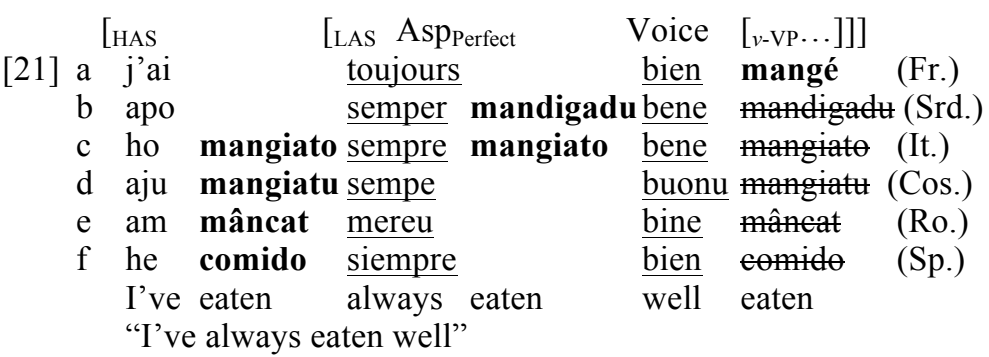

In contrast to what was observed with the finite verb (cf. 20e), the active participle moves least in French (21a), staying very low in the clause within the LAS to the right of the manner adverb "well" just above the $v$-VP, whereas in Calabrian (21d), Romanian (21e) and Spanish (21f) the active participle, unlike the finite verb in $(20 \mathrm{a}-\mathrm{c})$, moves to the highest available position in the HAS beyond the perfective aspectual projection spelt out by the "always" adverb. In Sardinian and Italian, on the other hand, the position of the active participle displays greater freedom, raising in Sardinian (21b) no higher than "always" in the LAS, and possibly above "always" to a position in the HAS in Italian (21c).

In the literature there is no general consensus regarding the correct interpretation of $\mathrm{V}$-movement to different clausal positions (for an overview, see Schifano 2011; in prep.), although traditionally there have been many attempts, as noted above, to relate the extent of movement to the richness or otherwise of the inflectional Agr of the verb, ${ }^{7}$ witness Baker's $(1985 ; 1988: 13)$ Mirror Principle and Bobaljik's (2002) Rich Agreement Hypothesis. In essence, approaches of this type attempt to drive syntactic operations from crosslinguistic morphological differences in individual languages. Admittedly, this view finds some initial support in the Germanic vs Romance contrast in (17a-b) where

6 Lois (1989: 34, 40), Cinque (1999: 45-49, 146-148), Abeillé and Godard (2003), Monachesi (2005: 134-136).

7 Roberts (1985), Lightfoot and Hornstein (1994), DeGraff (1997), Rohrbacher (1997), Vikner (1997) 


\section{A. LEDGEWAY}

the Romance verb form, undoubtedly the inflectionally richest of the two, raises the highest. However, a brief comparison of the results reported in (20)-(21) above suffices to dispel such an approach, inasmuch as all the Romance varieties we have examined are what may be termed inflectionally rich languages, yet they display some quite marked differences in the extent of finite lexical and non-finite V-movement. This conclusion is further substantiated by the observation that much of the rich inflection of the modern French verb, unlike that of the other varieties examined, is predominantly orthographic, yet it shows higher verb movement of finite lexical verbs to the HAS than all other varieties.

Thus, to conclude, we have seen that the rich comparative evidence of multiple verb positions across Romance forces us to recognize a richer functional structure for the clause than has traditionally been assumed. More generally, we have established that from an empirical and a theoretical perspective broadbrush characterizations of Romance as invariably involving overt V-raising prove neither descriptively nor explanatory adequate, inasmuch as a more nuanced picture has to be recognized. At the same time, this same evidence has highlighted the danger of assuming a direct correlation between the richness of inflection and the extent of $\mathrm{V}$-movement.

\subsection{Mapping the left periphery of the clause}

As seen in the previous section, one area of considerable interest in much recent syntactic research has been the investigation of the fine structure of the clause. Traditionally, the structure of the clause in a typical SVO language, of which almost all the modern Romance varieties are examples, has been taken to present (at least) the positions indicated in the linear template in (22a), exemplified from Italian in (22b):

$$
\begin{aligned}
& \text { [22] a Subject Aux Adverb Verb Object } \text { Adjunct(s) } \\
& \text { b Ugo ha sempre fatto la pasta a cena (It.) } \\
& \text { Ugo has always made the pasta at dinner } \\
& \text { "Ugo has always made pasta for dinner" }
\end{aligned}
$$

The linear arrangement in (22a-b) reflects the standard idea that the confines of the clauses can therefore be identified with the preverbal subject position situated at the left edge of IP and the 


\section{Testing linguistic theory and variation to their limits}

complement or adjunct position situated at the right edge of VP (23a). However, in recent years research within generative syntax has been increasingly directed towards the investigation of the fine structure of the left periphery, the syntactic space immediately to the left of the sentential core (23b), culminating in the seminal work of Rizzi (1997) which has given rise to a widely-accepted view of the fundamental cartography of the $\mathrm{C}$ (omplementizer)-domain (cf. also Benincà and Munaro 2010).

[23] a

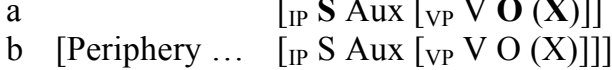

Significantly, a considerable amount of work on the split Cdomain has been conducted on the basis of the rich (dialectal) variation offered by Romance varieties (for an overview and relevant bibliography, see Ledgeway 2012a: 154-171), which in many cases provide invaluable overt evidence with which to map the fine structural organization of the left periphery. In particular, the left periphery, traditionally defined in terms of $\mathrm{CP}$ and its associated Spec(ifier) and head positions hosting wh-operators and complementizers (Chomsky 1986: §1), respectively, is now conceived as a split domain, hierarchically articulated into several fields and associated projections. Revealing in this respect are Italian topicalization examples such as (24a-c), where one of the constituents of the sentential core in (22b) conveying old/given information has been fronted to the left periphery and picked up, where available, by a resumptive clitic pronoun on the verb in the sentential core, a case of (clitic) left dislocation. ${ }^{8}$ This, however, does not exhaust all available structural possibilities, witness the examples in (25ad) where as many as two constituents have been fronted under (clitic) left dislocation, illustrating the fact that topic is a recursive category and capable of multiple realizations within the same utterance.

8 In these and following examples we indicate topicalized constituents by underlining, contrastively focalized constituents by small caps, and informationally focalized constituents with bold. 
[Topic $\mathrm{OLD}_{\mathrm{O} D} \quad[\mathrm{~S} \mathrm{~V}$ Adv O (X)]]

[24] a [La pasta, [Ugo $1^{\prime}$ ha sempre fatta a cena $\left.]\right]$ the pasta Ugo it=has always made at dinner

b [ $\mathrm{Ugo}_{i}, \quad\left[\mathrm{Uiu}_{\mathrm{i}}\right.$ ha sempre fatto la pasta a cena $\left.]\right]$ $\mathrm{Ugo}_{\mathrm{i}} \quad \mathrm{he}_{\mathrm{i}}$ has always made the pasta at dinner

c [A cena, [Ugo ha sempre fatto la pasta]] at dinner Ugo has always made the pasta

\section{[Topic}

[25] a [Ugo $\mathrm{Ug}_{\mathrm{i}}$ pasta $\mathrm{j}_{\mathrm{j}}, \quad\left[\mathrm{lui}_{\mathrm{i}} \mathrm{l}^{\prime} \mathrm{j}\right.$ ha sempre fatta a cena $\left.]\right]$

$\mathrm{Ugo}_{\mathrm{i}}$ the pasta $\mathrm{he}_{\mathrm{i}} \mathrm{it}=$ has always made at dinner

b [La pasta ${ }^{U_{g O}} U_{i} \quad\left[l i_{i} l_{j}^{\prime}\right.$ ha sempre fatta a cena $\left.]\right]$ the pasta $_{j} \overrightarrow{U g o}_{i} \quad h_{i}$ it $=$ has always made at dinner

c [Ugo $\mathrm{Ug}_{\mathrm{i}}$ a cena [lui ha sempre fatta la pasta]]

Ugo at dinner he has always made the pasta

d [A cena, la pasta ${ }_{i}$ [Ugol' ${ }_{i}$ ha sempre fatta]]

at dinner the pasta Ugo it=has always made

Further support for the richly articulated structure of the left periphery comes from a consideration of focus structures such as the Italian examples in (26), where a constituent of the sentential core in (22b) is fronted under contrastive focus to correct a previous assertion (cf. 26a-c). Significantly, however, fronted focused constituents are not in complementary distribution with fronted topicalized constituents, as the traditional simplex CP structure with its single left-peripheral position would lead us to believe, but can co-occur with left-dislocated topics in the strict order Topic + Focus, as shown in (27a-d).

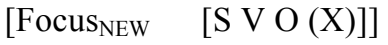

[26] a [SEMPRE [Ugo ha fatto la pasta a cena]]

always Ugo has made the pasta at dinner

b [A CENA [Ugo ha sempre fatto la pasta]]

at dinner Ugo has always made the pasta

c [LA PASTA [Ugo ha sempre fatto a cena]]

the pasta Ugo has always made at dinner 
Testing linguistic theory and variation to their limits

$[$ Topic + Focus $\quad[\mathrm{S} \mathrm{V} \mathrm{O}(\mathrm{X})]]$

[27] a [Ugo ${ }_{i}$ SEMPRE [lui ha fatto la pasta a cena]]

$\mathrm{Ugo}_{\mathrm{i}}$ always $\mathrm{he}_{\mathrm{i}}$ has made the pasta at dinner

b [ $\mathrm{Ugo}_{\mathrm{i}}$ A CENA [lui $\mathrm{i}_{\mathrm{i}}$ ha sempre fatto la pasta]]

Ugo at dinner he has always made the pasta

c [La pasta ${ }_{i}$ SEMPRE [Ugo l' ${ }_{i}$ ha fatta a cena]]

the pasta ${ }_{i}$ always Ugo $i_{i}=$ has made at dinner

$\mathrm{d}$ *[SEMPRE la pasta ${ }_{i} \quad$ [Ugo $\mathrm{l}^{\prime}{ }_{\mathrm{i}}$ ha fatta a cena]]

always the pasta $\mathrm{i}_{\mathrm{i}}$ ragm $\mathrm{it}_{\mathrm{i}}=$ has made at dinner

Evidence like this from Italian and other Romance varieties suggests that the existence of a single left-peripheral position is empirically inadequate. Rather, the relevant leftperipheral positions must be reconceived as distinct ragmaticsyntactic spaces along the lines of Benincà \& Poletto (2004), according to which we can identify from left to right at least two fields termed Topic and Focus, respectively (see also Cruschina 2012). Not only is this demarcation between Topic and Focus justified at a ragmatic-semantic level, in that elements appearing in the Topic field are generally interpreted as "old" or "given" information whereas the Focus field is typically associated with informationally "new" elements, but it also finds confirmation at the syntactic level. For instance, in contrast to elements appearing within the Topic field, which often call for a resumptive pronominal (clitic) where available (cf. 24a-b, 25a-d), those appearing within Focus (cf. 26d) typically prove incompatible with a pronominal copy (Benincà 2001: 43ff.). Moreover, we have already observed that topic is a recursive syntactic category allowing several reiterations within a given utterance, whereas focus is restricted to just one occurrence per utterance.

Robust evidence like this demonstrates that topicalized and focused constituents indeed target distinct spaces within the left periphery, forcing us to recognize a representation of the Cdomain along the lines of (28) below:

[28] [CP Comp [Topp Topic [FocP FOCUS [IP $\cdots$ ] ] ] ]

Complementizer positions

In addition to the Topic and Focus fields highlighted above, the left periphery of the clause also hosts complementizers. Now 


\section{A. LEDGEWAY}

alongside finite complementizers derived from QUOD/QUID and QU(I)A "(because $>$ ) that" which introduce tensed clauses (cf. (a) examples below), Romance varieties also present a series of non-finite complementizers derived from the prepositions DE "of, from" and AD "to" to introduce infinitival clauses (cf. (b) examples below), which to all intents and purposes parallel the use of their finite counterparts:

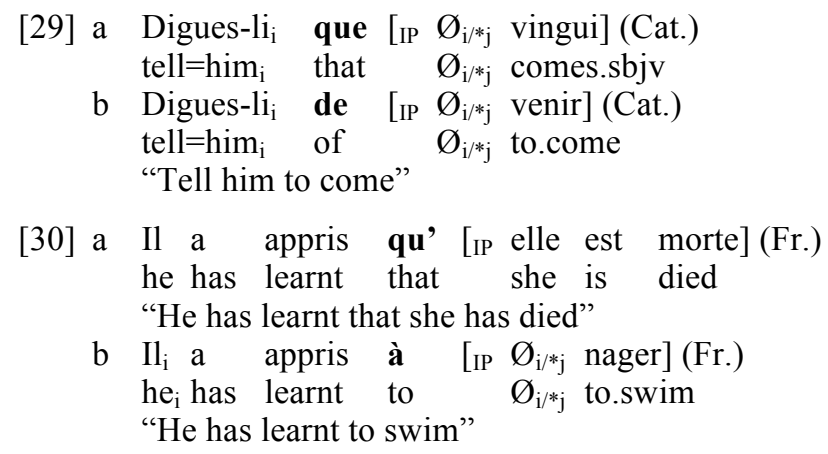

Despite appearances, the presumed parallelism between finite and non-finite complementizers is not, however, perfect, as revealed by their respective positions in relation to topics and foci: whereas finite complementizers precede topics and foci (31a), non-finite complementizers invariably follow both types of fronted constituent (31b).
[31] a So che, la data, [IP 1' ho sbagliata] (It.) I.know that, the date, it= I.have mistaken
b So, la data, di [IP averla sbagliata] (It.) I.know, the date, of to.have=it mistaken "I know (that), the date, I got (it) wrong"

Evidence like this forces us to assume that the Topic and Focus fields outlined above are, in turn, closed off upwards by a higher complementizer position (termed Force) marking the illocutionary force of the clause and hosting such items as the Romance finite declarative complementizer que/che "that", and downwards by a complementizer position (termed Fin(iteness)) specifying the modality and/or finiteness of the clause and hosting such items as the Romance infinitival complementizers del $d i$ "of", as schematicized in (32). 
Testing linguistic theory and variation to their limits

$\left[\right.$ Periphery $q u e /$ che $_{\text {Force }}+\underline{\text { Topic }}+$ FoCUS $\left.+d e / d i_{\text {Fin }}[\mathrm{IP} \ldots]\right]$

Indeed, some Romance varieties present dual finite complementizer systems which appear to exploit both the higher and lower complementizer positions within the left periphery. Such is the case in Romanian and many southern Italian dialects, ${ }^{9}$ which contrast an indicative/declarative complementizer (QU(I)A "because" $>$ ) $c \breve{a} / c a$ that lexicalizes the higher complementizer position, and therefore precedes topics and foci (33a), and a subjunctive/irrealis complementizer (e.g. SI "if" > Ro. să) that lexicalizes the lower complementizer position, and therefore follows topics and foci (33b):

[33] a sunt sigură că pe Ion $1-$ am văzut (Ro.)

I.am sure that on Ion him=I.have seen

"I'm sure that I saw Ion"

b vreau MÂINE să meargă la meci (Ro.)

I.want tomorrow that he.go.sbjv to match

"I want him to go to the match TOMORROW"

Such dual complementizer systems are widely found in the dialects of southern Italy, as illustrated in Table 5 (Rohlfs 1969: 190; Ledgeway 2004a; 2005; 2006; 2009b; 2012b):

Table 5. Southern Italian dual complementizer systems

\begin{tabular}{|c|c|c|}
\hline It. & $\begin{array}{l}\text { penso che verrà } \\
\text { "I think that he'll come" }\end{array}$ & $\begin{array}{l}\text { voglio che lui mangi } \\
\text { "I want that he should eat" }\end{array}$ \\
\hline Sic. & pensu ca vèni & vògghiu chi mmanciassi \\
\hline Mes. & critu ca vèni & ògghiu mi mancia \\
\hline S.Cal. & pensu ca vèni & vogghiu mu (mi) mangia \\
\hline N.Cal. & criju ca vèni & vuogliu chi mmangia \\
\hline Sal. & crisciu ca vène & ogghiu си mmancia \\
\hline Nap. & pènsa ca vèna & vòglia cho mmanga \\
\hline N.Pgl. & pènsa ca vèna & vògghia cho mmanga \\
\hline Abr. & pènsa ca vèna & vòjja cho mmanga \\
\hline
\end{tabular}

Further compelling evidence for these two complementizer positions comes from those varieties which allow the

9 For Romanian see, among others, Dobrovie-Sorin (1994: 93-111), Motapanyane (2000: §4.2), and for southern Italy Calabrese (1993), Lombardi (1997; 1998), Ledgeway (1998; 2004a; 2005; 2006; 2007c), Manzini \& Savoia (2005, I: 455-501, 650-676). 


\section{A. LEDGEWAY}

simultaneous lexicalization of both positions around a fronted topic or focus constituent (a a case of so-called "recomplemenation"), including many early Romance varieties (34a-b; Wanner 1998; Paoli 2003a; Ledgeway 2004a: §4.3.2.2; 2005: 380-389; Vincent 2006), and a number of modern Italian dialects (34c; Paoli 2002; 2003a,b; 2005; D'Alessandro and Ledgeway 2010) and modern Ibero-Romance varieties (34d; Demonte and Fernández-Soriano 2009; Gupton 2010: 227-234; Villa-García 2010).
[34] a je te adjure par le vray Dieu que ta fille I you=beseech by the true God that your Tarsienne, que tu ne la donnes a mariage a Tarsienne that you nother= give to marriage to autre que a moy (OFr.) other that to me "I beseech you before God that you may give your daughter in marriage to me alone"
$b$ èy manifesta cosa che HOMO CHE SE AVE A it.is obvious thing that man that self $=$ has to DEFENDERE A LA PATRIA SOA INTRE LI AMICI E to.defend to the fatherland his among the friends and LI CANUSSIENTI SUOY cha ave a chesta parte gran the acquaintances his that has at this part big prerogativa e gran avantayo (ONap.) prerogative and big advantage "And it is abundantly clear that, a man who has to defend himself in his own country among his friends and acquaintances, has in this respect considerable privilege and advantage"
c so ditte ca dumane, a Urtone, gni lu zie, ca I.am said that tomorrow at Ortona with the uncle that nin gi da' ji (Arl.) not there $=$ he.must to.go "I said that tomorrow he shouldn't go to Ortona with his uncle"
d Din que o irmán de Iago que sabe xogar moi they.say that the brother of Iago that knows to.play very ben ao futbolín (Glc.) well at.the football "They say that Iago's brother is very good at football"

Finally, unique within Romance is the situation encountered in Gascon since around the sixteenth century, where the 
Testing linguistic theory and variation to their limits

[+finite] feature of affirmative root clauses is exceptionally spelt out in the systematic lexicalization of the lower complementizer position Fin through the complementizer que "that". ${ }^{10}$ Firm proof that que spells out the lower complementizer head is provided by the observation that, apart from object clitics, nothing can intervene between que and the finite verb such that all preverbal lexical subjects must occur to the left of que. This latter observation highlights the fact that, unlike in other Romance varieties, there is apparently no preverbal subject position within the sentential core in Gascon, such that all subjects have to be syntactically fronted to a topicalized (typically if old and definite; 35a) or focalized (typically if new and indefinite; 35b) position within the left periphery. These facts find an immediate explanation in the assumption that que lexicalizes the Fin position, since finiteness is standardly assumed to license nominative Case, hence Gascon would appear to have grammaticalized the locus of finiteness and, by implication, the licensing of nominative subjects within the left periphery (as happens in V2 varieties), rather than in the sentential core.

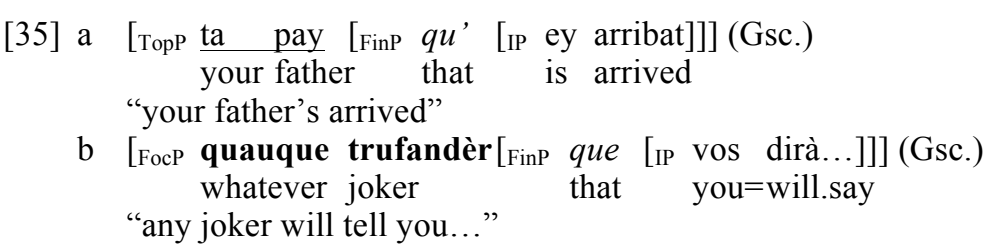

The fine structure of the left periphery can therefore be summarized as in (36):

[36] [Force que/che [Top Topic [Foc FOCUS [Fin de/di/che/cu/să [IP...]]]]]

\subsection{Interim conclusions}

The discussion so far has highlighted the importance of Romance data, and especially those from the still under-utilized non-standard varieties and dialects, in making us rethink some of our most basic assumptions about language structure and variation. In particular, we have seen that standard interpretations

10 Rohlfs (1970: 205-207), Wheeler (1988: 272-274), Sauzet (1989), Joseph (1992), Bec (1967: 47f.). 


\section{A. LEDGEWAY}

of the null subject parameter prove insufficient in terms of the limited range of null and overt pronominal subject types they predict, the limited predictive power of rich inflection in the distribution of null subjects, and the non-universality of inflection for person in licensing null subjects. Within the verbal domain we have established that the now classical typological distinction between $\mathrm{V}$-raising and non-V-raising languages, which places Romance among the former, proves empirically inadequate. By contrast, we have observed that the extent of V-movement across Romance varies enormously, revealing a whole host of different positions which can, in turn, be taken to spell out the vast range of functional projections that make up the rich architecture of the sentential core. In a similar vein, this rich functional design of the clause has been shown to extend to the left periphery, where the Romance evidence forces us to recognize a richly-articulated functional space composed, at the very least, of topic and focus fields sandwiched in turn, between two complementizer positions.

\section{What linguistic theory can do for Romance}

\subsection{Word order}

Undoubtedly one of the most striking differences between modern and medieval Romance varieties is manifested in the, often, radically differing word order patterns they permit in root clauses. By way of illustration, consider the old Neapolitan sentences in (37ab) and their modern Italian translations in (38-b):

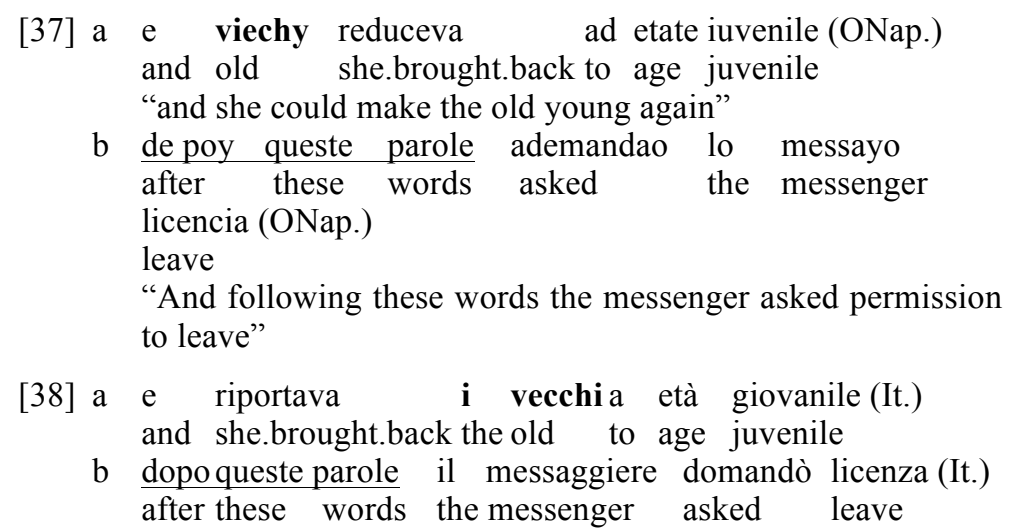


Testing linguistic theory and variation to their limits

(37a-b) exemplify a common early Romance structure in which the preverbal position is occupied by some constituent other than the subject, namely the direct object (viechy) and a nonsubcategorized adverbial phrase (de poy queste parole), respectively. In the former case, the fronted rhematic direct object, which conveys new information, constitutes an example of informational focus (Lambrecht 1994: ch. 5; Cruschina 2012), and contrasts sharply with many modern Romance varieties such as Italian (cf. 26-27), where preposing of rhematic constituents is only found under quite restrictive pragmatic conditions (namely, to license contrastive focus), insofar as rhematic objects conveying informational focus canonically occur in postverbal position (cf. 38a). Similarly, example (37b) demonstrates how when the preverbal position is occupied by a constituent distinct from the subject, the latter, whenever overtly realized, is generally required to follow the verb, giving rise to an apparent case of verb-subject inversion. Significantly, in this and similar examples of inversion the subject does not simply follow the verb but also precedes any other sentential constituents (subcategorized or otherwise), witness the order subject (lo messayo) + direct object (licencia) in (37b). In modern Italian, by contrast, postverbal subjects generally follow their associated objects and other sentential constituents, and in such cases are typically associated with rhematic interpretations, whereas the postverbal subject in (37b) is clearly thematic. Consequently, in the modern Italian translation of (37b) illustrated in (38b) the thematic subject obligatorily occurs in preverbal position.

Word order patterns such as those just considered, which can be easily replicated for other early Romance varieties (cf. $39 \mathrm{a}-\mathrm{g}$ ), have led a number of linguists to argue that medieval Romance word order is characterized by a verb second (V2) constraint. ${ }^{11}$ During this V2 stage sentences consist therefore of two principal parts (39a), a sentential core (IP) with fixed S V O

11 See Skårup (1975), Vanelli, Renzi and Benincà (1985), Vanelli (1986; 1999), Adams (1987), Dupuis (1989), Fontana (1993; 1997), Roberts (1993), Benincà (1995; 2006), Lemieux and Dupuis (1995), Ribeiro (1995), Vance (1997), Lombardi and Middleton (2004), Salvi (2004), Ledgeway (2007b; 2008). 


\section{A. LEDGEWAY}

Adv order on a par with what we have already witnessed in $\S 2.3$ for modern Romance, and a richly-articulated left periphery (CP) along the lines of (36) to whose lowest C(omplementizer) position (Fin) the finite verb raises in root clauses, where it is preceded by one or more elements fronted from the sentential core to the Topic and Focus fields to be assigned a pragmatically salient reading. In embedded clauses, by contrast, the left periphery generally hosts an overt Comp(lementizer) and the finite verb is consequently forced to remain within the sentential core, yielding the order $\mathrm{S}+\mathrm{V}+\mathrm{O}+\mathrm{Adv}(39 \mathrm{~b})$. Thus, as the following representative early Romance examples demonstrate, alongside $\mathrm{S}+\mathrm{V}+\mathrm{X}(39 \mathrm{c})$ we also frequently find in main clauses $\mathrm{O}+\mathrm{V}(\mathrm{S})(39 \mathrm{~d}), \mathrm{IO}+\mathrm{V}(\mathrm{S})(39 \mathrm{e}), \mathrm{O}_{\mathrm{PP}}+\mathrm{V}(\mathrm{S})(39 \mathrm{f})$, and $\mathrm{Adv}+\mathrm{V}(\mathrm{S})$ $(39 \mathrm{~g})$, whereas embedded clauses invariably display rigid $\mathrm{S}+\mathrm{V}+$ $\mathrm{O}+\operatorname{Adv}(39 \mathrm{~h})$ :

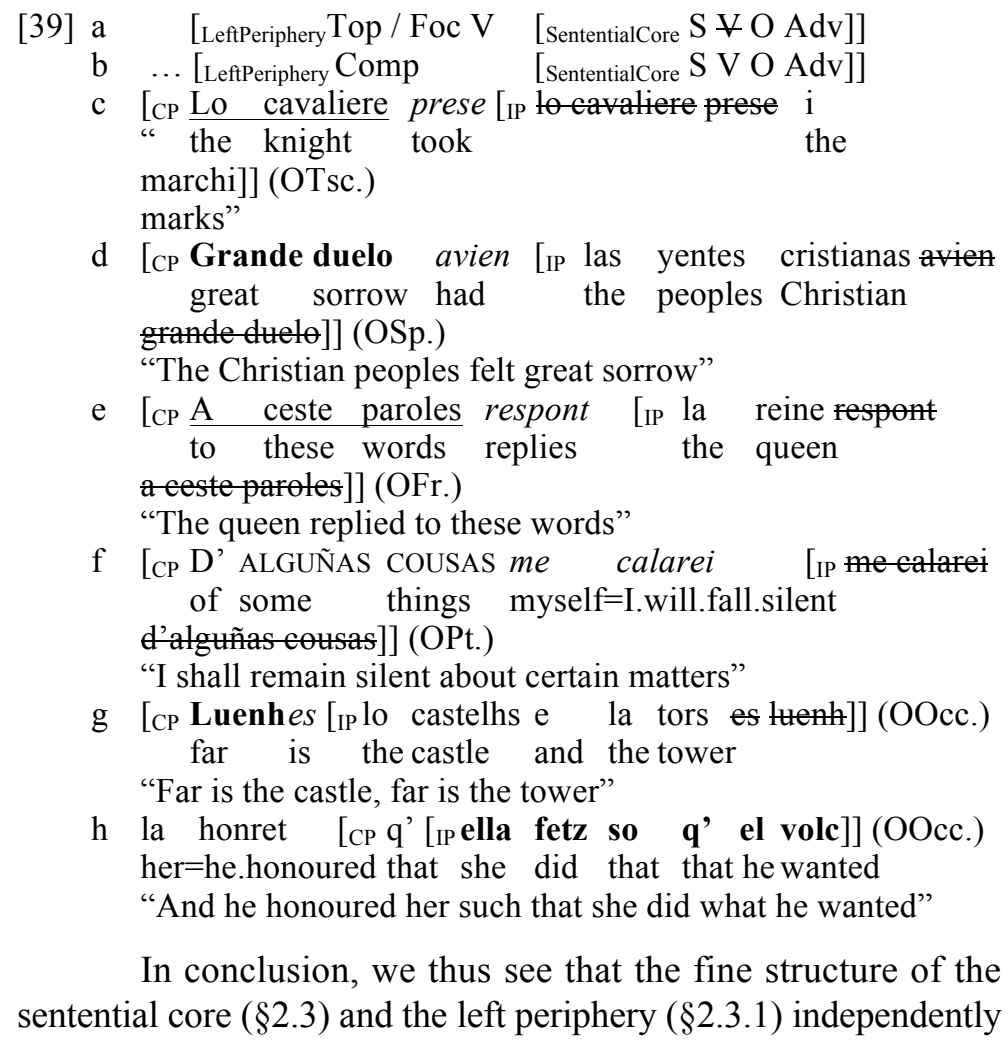


Testing linguistic theory and variation to their limits

established above on the basis of modern Romance data provide us with the necessary pragmatico-syntactic tools to interpret the facts of medieval Romance word order.

\subsection{Pro-drop parameter revisited}

Returning to our observation regarding the distribution of null subjects in medieval Romance (cf. examples (15)-(16) in §2.1), this same generalized raising of the finite verb to C(omp) under V2 also provides us with an elegant and highly natural explanation for the asymmetric distribution of null subjects in early Romance. In particular, when the verb raises to the vacant $\mathrm{C}$ position, null subjects are freely licensed (40a), whereas in subordinate clauses, where the finite verb is forced to remain in situ within the sentential core, pronominal subjects must be phonologically expressed (40b), although not interpreted as emphatic or contrastively-focused.

[40] a Si Ø errent tant en tele maniere qu' [...] (OFr.) so (they) wander so.much in such way that "they thus wandered so much in such a way that $[. .$.$] "$

b Endementiersque il regadoient les letres et la while that they looked.at the letters and the damoisele, que il plagnoient sa mescheance (OFr.) young.lady that they regretted her misfortune "While [that] they looked at the letters and the young lady, [and that] they regretted her misfortune"

This asymmetrical distribution leads us to conclude that null subjects in medieval Romance were not licensed exclusively, if at all, by rich verb inflection for person and number, but, by a property which the finite verb uniquely acquires by raising to the vacant $\mathrm{C}$ position, presumably the locus of finiteness in medieval Romance (cf. Ledgeway 2012a: \$3.4.1).

Interestingly, this archaic pattern has been exceptionally retained in modern Corsican (Marchetti 1974: 25, 51, 85, 94, $119)$, which behaves as a canonical Romance null subject variety in root clauses (41a-b), but which in embedded contexts usually requires referential (41a-c) and non-referential (41d) pronominal subjects to be overtly realized, albeit in reduced clitic form (cf. tonic/clitic eio/e, o (1sg), tù/tu (2sg), ellu/ella / (e)llu/(e)lla (3m/fsg), noi/no (1pl), voi/vo (2pl), elli/elle / 


\section{A. LEDGEWAY}

(e)lli/(e)lle $(3 \mathrm{~m} / \mathrm{fpl}))$. This distribution of null and overt pronouns is however only superficially similar to medieval Romance, in that modern Corsican is not a V2 variety and the finite verb occurs in the sentential core in all cases, irrespective of the realization of the pronominal subject. However, when the finite verb does raise to the vacant $\mathrm{C}$ (omplementizer) position, as happens in polar interrogatives (41e), realization of the clitic subject pronoun is blocked in a similar fashion to what was seen for medieval Romance (cf. 40a).

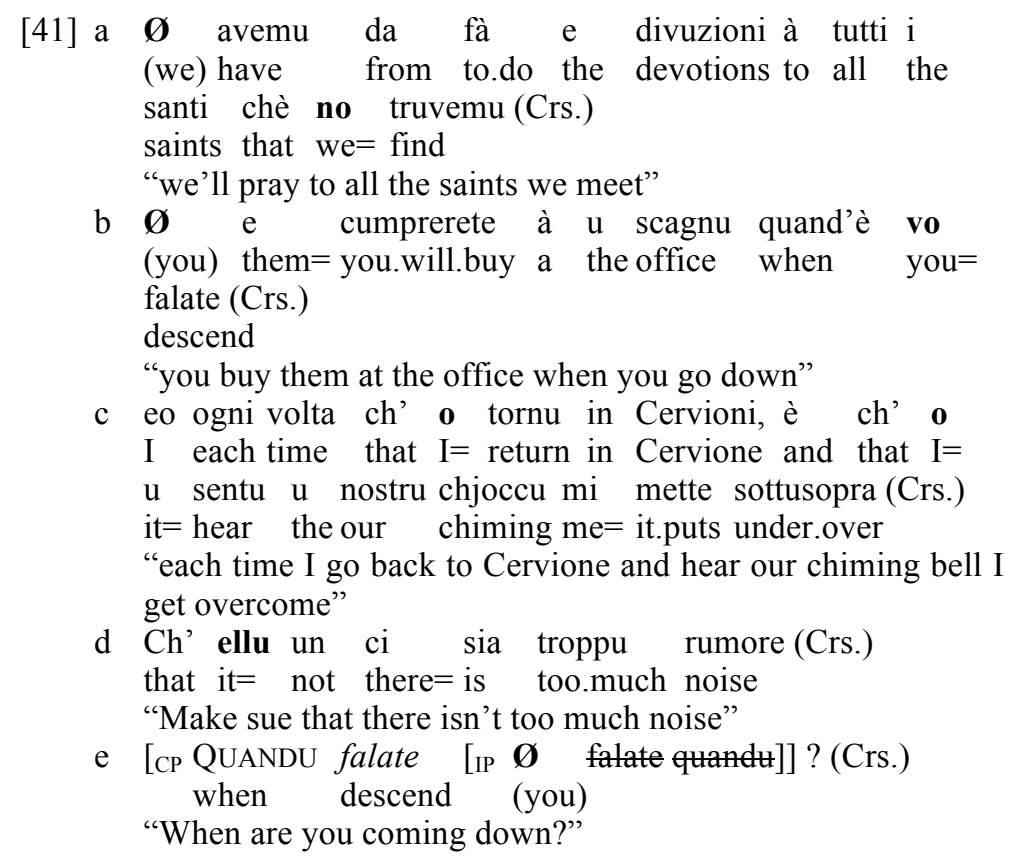

\subsection{Placiti cassinesi}

We now turn to the area of Romance philology and, in particular, the Placiti cassinesi (Bartoli 1944-45; Castellani 1973: 59-76; Bianchi, De Blasi and Librandi 1993: 211-212). Ignoring the Indovinello veronese, the Latin features of which are hardly negligible, these four brief, formulaic, sworn declarations composed in Capua, Sessa Aurunca and Teano (all situated in the modern-day southern Italian region of Campania) and dating between 960 and 963 are generally taken to represent the first documented attestations of the vernacular within the Italian 


\section{Testing linguistic theory and variation to their limits}

Peninsula. Below is reproduced the first of these, the Placito capuano from March 960, which relates to a land dispute between the abbot of Montecassino and a certain Rodelgrimo who claimed, through inheritance, ownership of the lands which the abbot maintained had been the property of the monastery of St. Benedict of Montecassino for thirty years. In the absence of any official documentation of ownership, the judge ordered the abbot to produce three witnesses to authenticate his claim, each of which was reported to have sworn the oath in (42):

[42] Sao ko kelle terre, perkelle fini que ki contene, I.know that those lands for those confines that here contains trenta anni le possette parte sancti Benedicti thirty years them $=$ possessed party saint.obl Benedict.obl "I know that, those lands, within those borders which are contained here [in the document/map before me], have belonged for thirty years to the part [= monastery] of St. Benedict [of Montecassino]"

Although a very short text, the Placito capuano is not without its problems, raising a number of qualitative and interpretive issues for the philologist. In particular, given the extremely brief and formulaic nature of the text, it is legitimate to question what is the value, if any, of the linguistic evidence that such a short piece can genuinely offer the historian of the language. Indeed, this is a problem which arises with many of the earliest attestations of the Romance vernacular including, for example, the earliest Romance text, the Strasbourg Oaths of 842, another short sworn oath produced in an early French dialect of disputed origin. ${ }^{12}$

Another unresolved issue thrown up by the Placito capuano concerns the correct reconstruction of the pragmaticosemantic interpretation of the fronted constituents stacked up at the beginning of the embedded clause (namely, kelle terre, per kelle fini..., trenta anni), our reading of which is without doubt greatly hindered by the limited nature of our textual evidence. Again this is a frequent problem faced by philologists reading early texts, which in many cases only offer a rather brief glimpse of the language, especially when they only exist in fragmentary

12 See Tabachovitz (1932), Ewert (1935), Castellani (1969; 1978), López (1994), Ayres-Bennett (1996: 16-30). 


\section{A. LEDGEWAY}

form, and whose linguistic physiognomy is often deliberately limited by the specific style and register of the text type.

A final observation concerns the appearance of the complementizer ko "that" in (42). Contrary to our expectations in light of the discussion of dual complementizer systems above (cf. Table 5 in \$2.3.1), the epistemic main clause predicate sao "I know" selects for an indicative clausal complement headed, not by the expected indicative complementizer $c a$, but by what appears to be the subjunctive complementizer ko. How are we then to interpret the appearance of $k o$ in this instance? Is it an example of a scribal error, or should it be taken at face value? As we shall see below, a consideration of this question in light of our preceding discussion of the fine structure of the left periphery provides an illuminating solution.

Putting together the results of the discussions of the previous sections regarding the fine structure of the left periphery of the clause $(\$ 2.3)$ and the philological evidence of the Placito capuano, it becomes clear that a knowledge of the relevant linguistic and philological facts can profitably complement one another. In particular, we begin by observing how, despite only providing a glimpse of the early vernacular, the Placito capuano is of immense interest both to the historian of the language and the historical linguist since, although a very short text, it is nonetheless astonishingly rich in linguistic evidence. More specifically, it is quite remarkable that such a short text, and the first one from the Italian Peninsula no less, should provide such extensive early evidence of the fine structure of the left periphery and, above all, incontrovertible proof for the existence of the two left-peripheral fields postulated in $\$ 2.1$, which, in turn, hold the key to a proper pragmatico-semantic interpretation of the fronted constituents stacked up at the beginning of the embedded clause. In particular, the rigid ordering of the Topic + Focus fields postulated in $\$ 2.1$, together with our observations regarding the potential recursiveness of topics but not focus, which is limited to a single occurrence, allows us to infer that the left periphery of the embedded clause hosts two thematicizations within the Topic field, namely kelle terre "those lands" (picked up by the resumptive clitic pronoun le 
Testing linguistic theory and variation to their limits

"them") and per kelle fini que ki contene "with those borders which are contained here", and a contrastive focus trenta anni "(for) thirty years" within the Focus field, as illustrated in (43).

$$
\begin{aligned}
& \text { Sao [Force ko [TopP kelle terre, per kelle fini que } \\
& \text { I.know that those lands for those confines that } \\
& \text { ki contene, [FocP TRENTA ANNI [IP le possette parte } \\
& \text { here contains thirty years them= possessed part } \\
& \text { sancti Benedicti ]]]] } \\
& \text { saint.obl Benedict.obl }
\end{aligned}
$$

Turning now to the unexpected used of the complementizer $k o(<$ QUOD) rather than $c a$, this too finds a principled explanation in terms of the structural organization of the complement clause. As demonstrated in Ledgeway (2004a; 2005), in the early dialects of southern Italy, including those of Campania, the distribution of the two complementizers co/che $(<\mathrm{QUOD} /$ QUID) and $c a(<\mathrm{QU}(\mathrm{I}) \mathrm{A})$ is not quite as neat as the traditional descriptions reviewed in $\$ 2.3 .1$ would lead us to expect (cf. Table 5). Whereas all types of subjunctive clause are introduced by $c h e$, indicative complement clauses are headed either by $c a$ or che. Simplifying the facts somewhat (for detailed discussion, see Ledgeway 2005: §3), it will suffice to note here that either $c a$ (44a) or che (44b) are employed when the left periphery of an embedded indicative clause does not contain any topics or foci, whereas che alone is found in the presence of fronted topics/foci (44c), as witnessed by the following old Neapolitan examples:

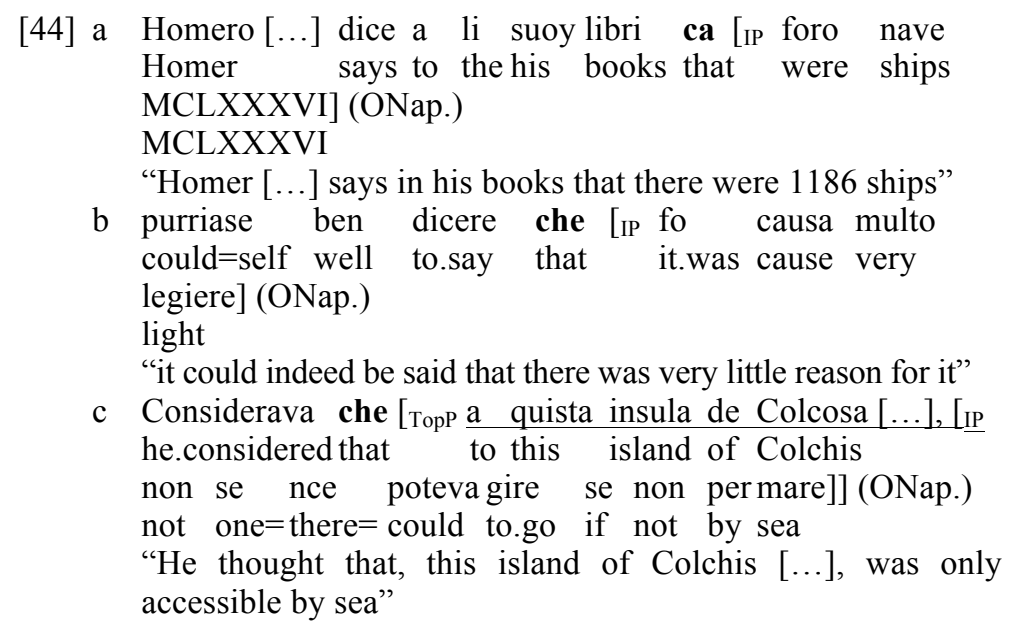




\section{A. LEDGEWAY}

In view of these distributional facts, it is possible to argue that old Neapolitan had just one indicative complementizer $c a$ generated in the lowest complementizer position (Fin) which, whenever raised to the higher complementizer position (Force), as proves obligatory whenever topics or foci are present, is morphologically spelt out in the form che (namely, $c a_{F i n} \Rightarrow c h e_{F o r c e}$ ). In short, the overt form assumed by indicative co/che is interpreted as nothing more than the surface morphological reflex of raising $c a$ from its base position to the higher complementizer position within the left periphery. Indeed, this analysis is directly supported by old Neapolitan recomplementation examples such as (34b) above where, crucially, the higher complementizer invariably surfaces in the morphological form co/che but the lower position is always spelt out as $c(h) a$, and never vice versa.

In this light, we can now return to the apparently erroneous selection of $k o$ in the Placito in (42). It turns out after all that the use of $k o$ here is not a scribal error or a singular mistake, but reflects the availability and use of two different complementizer positions determined by the informational structure of the embedded clause (cf. 45a) which, as we have seen in (43), contains a contrastively focused constituent preceded by two topicalized constituents. It is the activation of these TopicFocus fields in the embedded left periphery which is directly responsible for the presence of ko, inasmuch as the complementizer $c a$ is forced to move to the higher complementizer position in the presence of fronted topics or foci where it is spelt out as $k o$ (45b). It now comes as no surprise therefore that the complementizer $c a$ (or its graphic variants $k a, c h a$ ) should not be employed in (42).

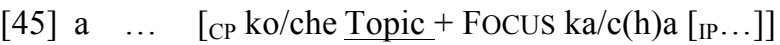

b Sao [CP ko $\mathbf{k o}_{i}$ kelle t., per kelle... TRENTA ANNI ka ${ }_{i}$ [IP...]]

This example also highlights the dangers of dismissing too hastily the linguistic attestations offered to us by even the most meagre of philological evidence. In this particular case, the Placito capuano provides an invaluable early example of the $c a$ $\Rightarrow$ che alternation, which is not attested again in our textual record for the Campania region for at least another 350 years. Thanks however to this early attestation, we can conclude with 


\section{Testing linguistic theory and variation to their limits}

confidence that the relevant complementizer alternation and associated positions licensed by the absence/presence of fronted topics and foci, otherwise richly attested in texts from the fourteenth century onwards (Ledgeway 2004a; 2005; Vincent 2006), must date back to at least the tenth century. Of course, it might be objected that the linguistic evidence of the texts is so formulaic that its value for the linguist is questionable on a number of counts. Indeed, a comparison of the Placito capuano with the other three Placiti cassinesi produced three years later in the nearby localities of Sessa Aurunca (46a) and Teano (46b-c) reveals such an extraordinarily high level of structural, discourse and lexical uniformity across all four texts that it would be naïve to imagine that all four sworn oaths represent authentic testimonies of the spontaneous spoken vernacular of the time.

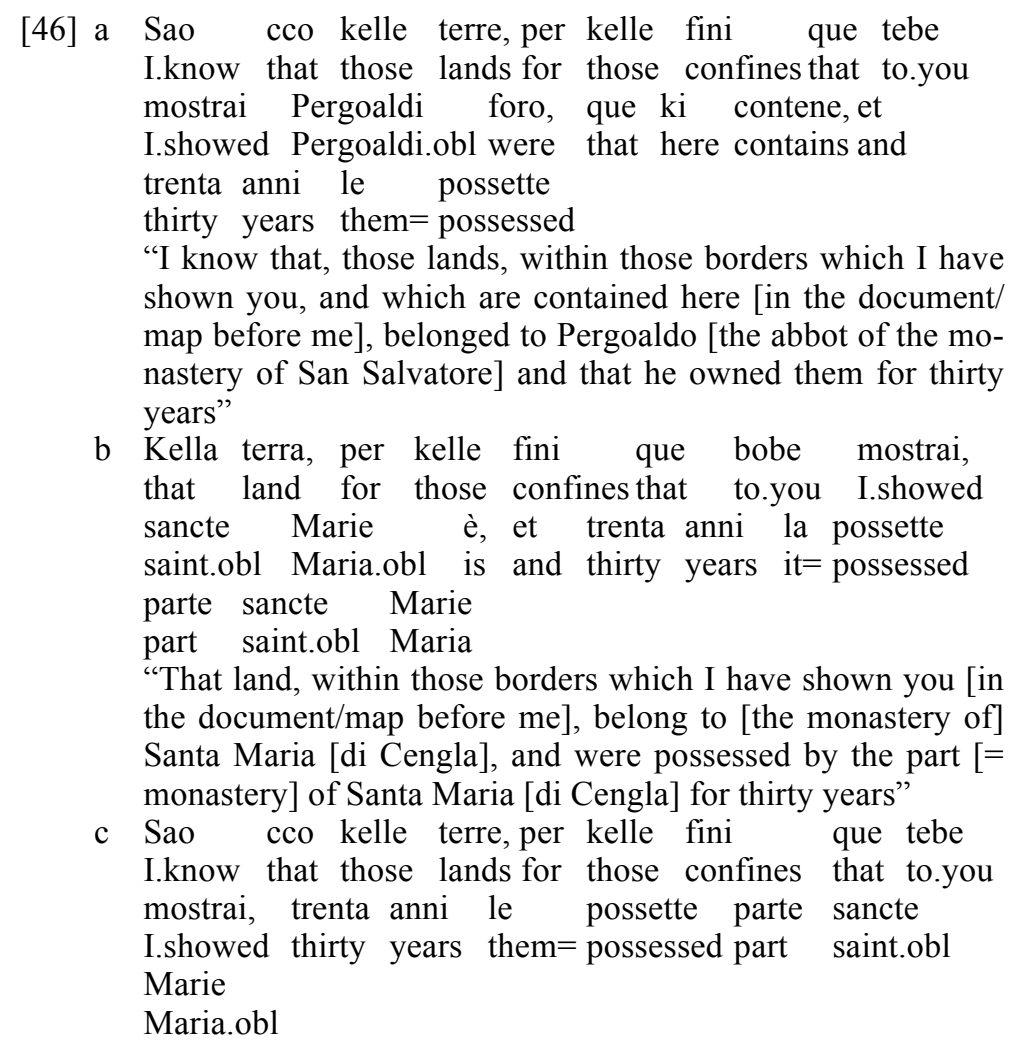




\section{A. LEDGEWAY}

"I know that those lands, within those borders which I have shown you [in the document/map before me], have belonged for thirty years to the part [= monastery] of Santa Maria [of Cengla]"

On the contrary, given the nature of the four oaths, which all had the specific purpose of persuading the court that a set of disputed lands had been in the possession of a given monastery for thirty years and consequently a legitimate part of the latter's estate, it is more than likely that the illiterate peasants enlisted by the Church to serve as "independent" witnesses, presumably under the promise of personal financial reward, were given very precise instructions regarding what they were required to swear under oath. Nonetheless, it would be rash to disregard the evidence of these four short, highly formulaic written testimonies on these grounds alone; rather, given the Church's deliberate efforts to place presumably authentic-sounding words and structures of the vernacular in the mouths of their witnesses, it is still possible to see in the language of these four texts a deliberate hypercharacterization of some of the most salient traits of the spoken language of the time such as the fronting of topicalized and focused constituents, which still constitutes to this day a characteristic feature of the spoken, rather than written, registers of Romance (cf. Duranti and Ochs 1979).

The discussion in this section has demonstrated that, when theory and philological evidence are considered together, the results of traditional philological and linguistic scholarship can be considerably enhanced. More specifically, we have seen that current theoretical assumptions about the design and architecture of the left periphery of the clause provide us with some novel and powerful tools to shed light on the interpretation and linguistic choices of one of the earliest Romance texts. At the same time, the Placiti cassinesi provide independent and robust evidence for these same syntactic assumptions. In short, and as abundantly demonstrated in this case study, linguistics and philology should complement each other to produce enlightening results, rather than be seen as alternatives to be pursued in isolation from each other. 
Testing linguistic theory and variation to their limits

\subsection{Dual complementizer systems}

Above in $\$ 2.3 .1$ we observed how Romanian and a number of southern Italian dialects employ a dual complementizer system (cf. Table 5) which distinguishes between a realis complementizer derived from QUIA $(>c a, c \breve{a})$ and an irrealis complementizer derived from QUID ( $>c h e, c h i)$, QUOD $(>c u)$, MODO $(>m u, m a$, $m i)$ or SI $(>s \breve{a})$ : while the former heads clauses selected by declarative and epistemic predicates (typically marked by the indicative; 47a), the latter is employed after predicates such as volitionals that characterize the state or events of their complements as unrealized at the time of speaking (typically marked by the subjunctive; $47 \mathrm{~b}$ ).

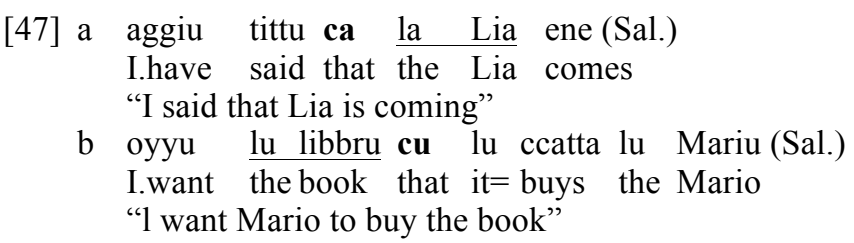

We also saw that both complementizers differ with respect to their relative positions in conjunction with fronted topicalized and focused constituents. For instance, as the preceding Salentino examples demonstrate, while $c a$ precedes all such fronted elements (47a), cu must follow (47b). Facts like these led us to propose in terms of Rizzi's (1997) split CP perspective that the realis complementizer (e.g. $\mathrm{ca}$ ) lexicalizes the higher Force head and the irrealis complementizer (e.g. cu) the lower Fin head, as sketched in (48):

[48] [ForceP $\boldsymbol{c a}$ [TopP Top [FocP Foc [FinP $\boldsymbol{c u}$ [IP ...]]]]]

A further distinction between the two complementizers which, at first sight, does not seem to immediately follow from (48) concerns their phonological realization (Calabrese 1993; Terzi 1994; 1996; Ledgeway in press). For example, while in Salentino ca must always be pronounced (49a), cu may optionally remain unpronounced (49b), a case of what we may term C-drop.

[49] a te prumettu *(ca) tornu (Sal.)

you=I.promise that I.return

"I promise you that I will return" 


\section{A. LEDGEWAY}

b ogghiu (cu) llu faci stare cittu (Sal.)

I.want that it=you.make to.be quiet

"I want you to shut him up"

Strikingly, even in those Romance varieties which do not display a dual complementizer system it is not infrequent for the finite complementizer (viz. que/che) to remain phonologically unpronounced, on condition that it introduces an irrealis complement $(50 \mathrm{~b}, 51 \mathrm{~b}, 52)$, but not, crucially, when it introduces a realis complement $(50 \mathrm{a}, 51 \mathrm{a}) .^{13}$

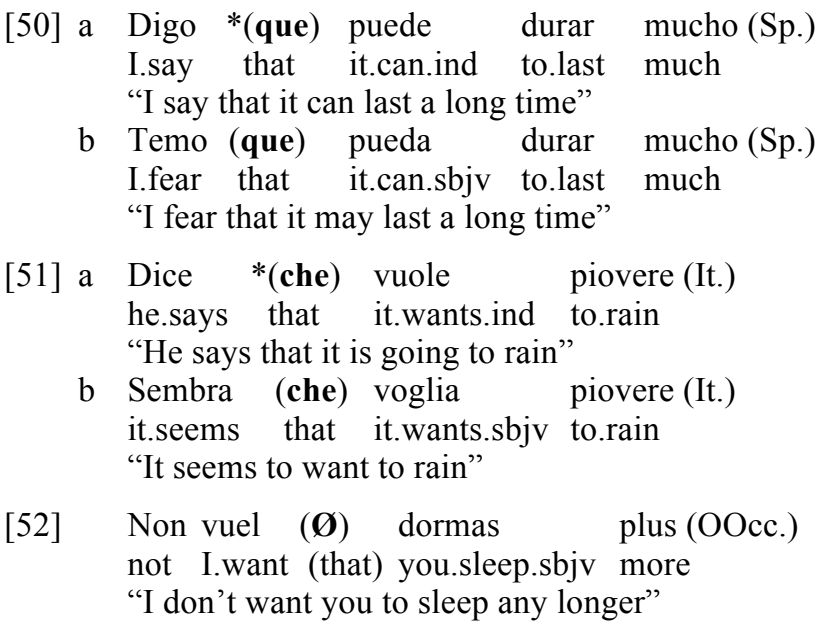

In view of the superficial similarity in the conditions regulating the distribution of C-drop in varieties with dual complementizer systems and languages such as Spanish, Italian and Occitan with apparently only one complementizer, it is tempting to extend the analysis of dual complementizer systems to languages of the latter type. In particular, we have established on the basis of dual complementizer systems that $\mathrm{C}$-drop is a property uniquely licensed by the lowest $\mathrm{C}$-related position, presumably involving a residual V2 effect with raising of the modally-marked finite verb to $\mathrm{C}_{F i n}$ in the absence of the irrealis complementizer (Poletto 2001), but not by the realis complementizer which lexicalizes the highest C-related position Force and hence unavailable to

13 Cf. Wanner (1981), Giorgi and Pianesi (1997; 2004), Poletto (2001), Scorretti (1994), Giorgi (2009: 1840-1845; 2010: 43-47). 
finite verb raising under V2. By the same token, in its irrealis uses standard Romance que/che must also lexicalize Fin, thereby explaining its complementary distribution with finite verb raising under C-drop, in contrast to its realis uses where it lexicalizes the highest position Force.

In short, we are led to conclude that the dual complementizer system explicitly attested for such varieties as Romanian and the dialects of southern Italy must also be assumed to hold more generally for Romance where, despite the difference between the two complementizers not being overtly lexicalized, the relevant distinction between the two homophonous complementizers (que/che) is marked indirectly by their differential positions within the left periphery and their compatibility with C-drop (53a-c).

[53] a [Force $\varnothing \quad$ [Topic, Focus [Fin que/che $\left.\left.e_{+ \text {Sbjv }}\left[\mathrm{IIP}_{\text {Sbjv }}\right]\right]\right]$

b [Fore $\varnothing \quad$ [Topic, Focus $\left.\left.\left[\begin{array}{llll}\text { Fin } & V_{\text {Sbjv }} & {\left[{ }_{\text {IP }}\right.} & \forall_{\text {Sbj }}\end{array}\right]\right]\right]$

c [Force $q u e /$ che $e_{+ \text {Ind }}$ [Topic, Focus [Fin $\quad \varnothing \quad\left[\right.$ IIP $\left.\left.\left.\mathrm{V}_{\text {Ind }}\right]\right]\right]$

\subsection{Noun positions}

Oversimplifying somewhat, prenominal and postnominal adjectives positions typically correlate with the following respective interpretations in the modern standard varieties of Romance: ${ }^{14}$ (i) inherent / non-inherent (54a); (ii) descriptive / distinguishing (54b); (iii) subjective / objective (54c); and (iv) figurative / literal (54d).

[54] a su británica reserva vs la Embajada británica (Sp.) his British reserve the Embassy British "his British reserve" vs "the British Embassy"

$b$ une courte lettre vs une jupe courte (Fr.) a short letter a skirt short "a short letter" vs "a skirt that is short"

c un (formidabil) om (formidabil) (Ro.) a tremendous person tremendous "a tremendous person"

14 See further Arnholdt (1916), Sandfeld and Olsen (1960: 98-114), Alisova (1967), Reiner (1968), Lapesa (1975), Vincent (1986; 2007: 57-61), Bernstein (1993), Giorgi and Longobardi (1991), Bosque (1996), Berruto (1998), Pountain (1998), Demonte (1999), Abeillé and Godard (1999), Radatz (2001), Cinque (2010), Gonzaga (2004), Ledgeway (2007a). 


\section{A. LEDGEWAY}

d la grisa quotidianitat vs la camisa grisa (Cat.) the grey daily.routine the shirt grey "the grey (= dull) daily routine" vs "the grey shirt"

Matters were, however, quite different in early Romance, insofar as contrastive readings were not necessarily associated with the postnominal position as in modern Romance, but could equally be licensed in the prenominal position (Ledgeway 2007a; 2009a: 214f; Vincent 2007; Thiella 2008: ch. 4; Giusti 2010: 599-609). ${ }^{15}$ This is illustrated in the following near minimal pairs, where the adjective in each case invariably gives rise to a contrastive reading irrespective of its pre- or postnominal position.
[55] a pro christian poblo vs lo nom christiien (OFr.) for Christian people the name Christian "for the Christian people" vs "the Christian name"
b con tondo giro vs uno tagliere with round circle a chopping.board round "with a round circle" vs "a round chopping board"
c li spangnoli soldati vs le compangnie spangnole (ONap.) the Spanish soldiers the companies Spanish "the Spanish soldiers" vs "the Spanish troops"

Strikingly similar is the situation found in modern Walloon (Bernstein 1991), where all adjectival classes (apart from those expressing nationality) occur in prenominal position (56a-c), perhaps representing a conservative feature, although one cannot also exclude the (reinforcing) influence of neighbouring Flemish varieties.

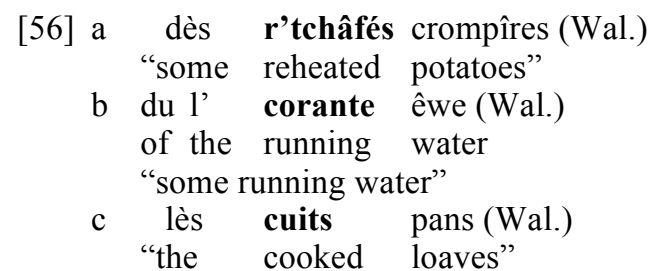

By contrast, in a number of, especially non-standard, Romance varieties including Occitan (57a; cf. Wheeler 1988: 268), Sardinian (57b; cf. Jones 1993: 42) and central-southern Italian dialects

15 Ledgeway (2007a; 2009a: 241f.), Vincent (2007), Thiella (2008: ch. 4), Giusti (2010a: 599-609). 
(57c; cf. Rohlfs 1969: 330; Ledgeway 2007a), the prenominal adjectival position is extremely restricted and generally replaced by the postnominal position, which is neutral to the contrastive vs non-contrastive distinction: ${ }^{16}$

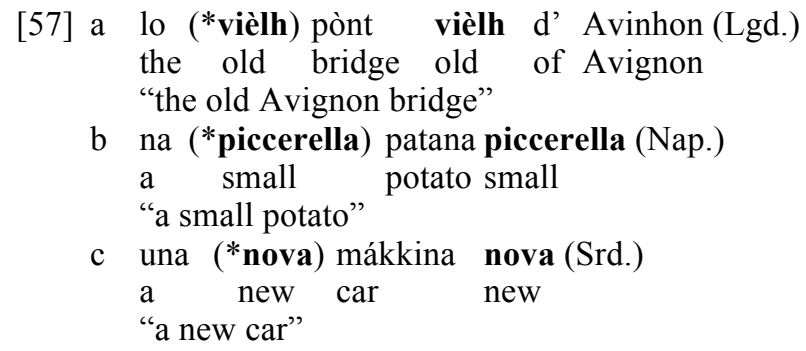

Building on our discussion and analysis in $\S 2.2$ of variable verb positions around different adverbial classes distributed across the clause, it is possible to make sense of the variation witnessed in (54)-(57) along parallel lines in terms of the varying extent of $\mathrm{N}$ (oun)-movement in different Romance varieties. In particular, distinct adjectival positions can be reinterpreted as the surface reflex of the head noun variously moving across a rigidly-ordered series of different adjectival classes situated immediately above the NP, as shown in the structural representation in (58):

\section{[58] (N) [aP1 $\operatorname{Adj}(\mathbf{N})[\operatorname{AP2} \operatorname{Adj}(\mathbf{N})[\operatorname{ap3} \operatorname{Adj}(\mathbf{N})[\operatorname{AP4} \operatorname{Adj}[\mathrm{NP} \mathbf{N}]]]]$}

Assuming the much-simplified structure in (59a) in which $\mathrm{AP}_{1}$ and $\mathrm{AP}_{2}$ can be broadly understood as the "areas" in which non-contrastive and contrastive adjectives, respectively, are generated, we can now formally capture in a highly simple manner the differences between the non-standard varieties in (57a-c) on the one hand and standard Romance varieties (54a-d) on the other: in the former the nominal head typically raises to the highest available position above the highest adjectival projection $\left(\mathrm{AP}_{1}\right)$, which hosts non-contrastive adjectives from where it precedes both non-contrastive and contrastive adjectives (59b), whereas in the latter the noun only targets the higher adjectival

$16 \mathrm{Cf}$. the postnominal position of the adjectives in (57a-c) with the corresponding prenominal position in their French (le vieux pont d'Avignon) and Italian (una piccola patata; una nuova macchina) translations. 


\section{A. LEDGEWAY}

projection $\left(\mathrm{AP}_{1}\right)$, from where it precedes non-contrastive adjectives but follows those with a contrastive reading $(59 \mathrm{c})$ :

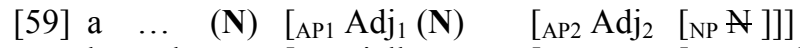

$$
\begin{aligned}
& \mathrm{b} \text {...lo pònt [AP1 vièlh pònt } \quad[\mathrm{AP} 2 \quad[\mathrm{NP} \text { pènt }]]](\mathrm{Lgd} .) \\
& \text { c ...le [AP1 vieux pont [AP2 [NP pont ]] }(\text { Fr.) }
\end{aligned}
$$

By the same line of reasoning, we can explain the frequent prenominal position of contrastive adjectives in early Romance (cf. $55 \mathrm{a}-\mathrm{c}$ ) by assuming that N-raising is only optional in the early varieties (60a-b), an archaic pattern still preserved to the presentday in Walloon where the nominal head barely moves at all (60c):

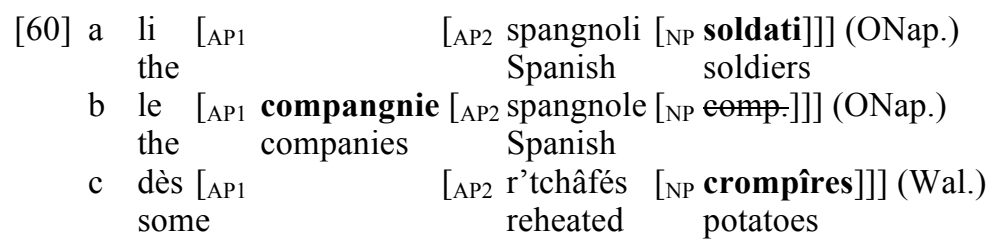

In conclusion, we see that there are truly striking parallels between the nominal and verbal domains and the functional structures associated with these, as revealed by the fixed positions of distinct classes of adjectival and adverbial modifiers, respectively. In particular, we have seen how different diachronic and diatopic varieties of Romance provide clear evidence for some considerable microvariation in terms of the extent of $\mathrm{N}$ movement. Among the various patterns observed, we also identified a strong diachronic tendency for Romance nouns to climb progressively higher within the available nominal functional structure, the end result of which has given rise in a number of non-standard varieties to a semantic neutralization of the erstwhile interpretive difference between contrastive and non-contrastive adjectival readings.

\section{Conclusion}

Although modern linguistics as a discipline developed in large part out of the philological study of individual languages and language families such as Romance, it is a striking characteristic of contemporary research in both Linguistics and in Romance Studies that the traditional link between the two disciplines is 
Testing linguistic theory and variation to their limits

often not as strong and prominent as it might be. To be sure, analyses within Romance linguistics which fail to take account of the most enlightening ideas and principles of linguistic theory risk overlooking and/or misconstruing the relevance of all or part of the available empirical evidence they are so at pains to correctly reconstruct, evaluate and interpret. By the same token, linguistic analyses which are blindly driven by theory-internal considerations with little or no real interest in actual data such as those offered by textual corpora and the numerous dialectal varieties of Romance run the risk of presenting a largely idealized and, by definition, necessarily selective representation of the available linguistic evidence. The result is a partial theory which is only capable of accounting for a subset of the available data that largely ignores the imperfections and irregularities characteristic of authentic linguistic productions. The discussion of the preceding sections, by contrast, has demonstrated that when theory and Romance evidence are considered together, the results of traditional Romance and linguistic scholarship can be considerably enhanced.

\section{Bibliographical references}

Abeillé A. \& Godard D. (1999). "La position de l'adjectif épithète en français: Le poid des mots", Recherches linguistiques de Vincennes 28: 9-32.

Abeillé A. \& Godard D. (2003). "Les prédicats complexes dans les langues romanes", in D. Godard (ed.) Les langues romanes: Problèmes de la phrase simple. Paris: Editions de la CNRS, 125-184.

Adams M. (1987). Old French, Null Subjects, and Verb Second Phenomena. UCLA: unpublished thesis.

Alisova T. (1967). "Studi di sintassi italiana. II. Le posizioni dell'aggettivo nel gruppo sintattico del sostantivo", Studi di filologia italiana 25: 250-313.

Arnholdt K. (1916). Die Stellung des attributiven Adjektivs im Italienischen und Spanischen. Greifswald: Von Bruncken.

Ayres-Bennett W. (1996). A History of French through Texts. London: Routledge. 


\section{A. LEDGEWAY}

Badia i Margarit A. (1962). Gramática catalana (2 vols). Madrid: Gredos.

Baker M. (1985). "The Mirror Principle and Morphosyntactic Explanation", Linguistic Inquiry 16: 373-416.

Baker M. (1988). Incorporation. Chicago: University of Chicago Press.

Bec P. (1967). La langue occitane. Montpellier: PUF.

Belletti A. (1990). Generalized Verb Movement. Turin: Rosenberg \& Sellier.

Belletti A. (ed.) (2004). Structures and Beyond. The Cartography of Syntactic Structures. Volume 3. Oxford: Oxford University Press.

Benincà P. (1994). "Un'ipotesi sulla sintassi delle lingue romanze medievali", in $\mathrm{P}$. Benincà (ed.) La variazione sintattica. Studi di dialettologia romanza. Bologna: il Mulino, 177-194.

Benincà P. (1995). "Complement Clitics in Medieval Romance: The Tobler-Mussafia Law", in A. Battye \& I. Roberts (eds) Clause Structure \& Language Change. Oxford: Oxford University Press, 325-344.

Benincà P. (2006). "A Detailed Map of the Left Periphery of Medieval Romance", in R. Zanuttini, H. Campos, E. Herberger \& P. Portner (eds) Crosslinguistic Research in Syntax and Semantics. Negation, Tense, and Clausal Architecture. Washington: Georgetown University Press, 53-86.

Benincà P. (2010). "L'ordine delle parole e la struttura della frase : La periferia sinistra", in G. Salvi \& L. Renzi (eds) Grammatica dell'italiano antico (II volumi). Bologna: il Mulino, I, 27-59.

Benincà P., \& Munaro N. (eds) (2010). Mapping the Left Periphery. The Cartography of Syntactic Structures, Volume 5. Oxford: Oxford University Press.

Benincà P. \& Poletto C. (2004). "Topic, Focus, and V2. Defining the CP Sublayers", in L. Rizzi (ed.) The Structure of $C P$ and IP. The Cartography of Syntactic Structures. Volume 2. Oxford: Oxford University of Press, 52-75. 
Testing linguistic theory and variation to their limits

Bernstein J. (1991). "DPs in French and Walloon: Evidence for Parametric Variation in Nominal Head Movement", Probus 3: 101-126.

Bernstein J. (1993). Topics in the Syntax of Nominal Structure Across Romance. CUNY: unpublished thesis.

Berruto G. (1998). "Sulla posizione prenominale dell'aggettivo in italiano", in G. Bernini, P. Cuzzolin \& P. Molinelli (eds) Ars linguistica. Studi offerti a Paolo Ramat. Rome: Bulzoni, 95-105.

Bianchi P., De Blasi N. \& Librandi R. (1993). I' te vurria parlà. Storia della lingua a Napoli e in Campania. Naples: Tullio Pironti.

Biberauer T., Holmberg A., Roberts I. \& Sheehan M. (2009). Parametric Variation. Null Subjects and in Minimalist Theory. Cambridge: Cambridge University Press.

Bobaljik J. (2002). "The Rich Agreement Hypothesis in Review", in Y. Abe (ed.) Complex Predicates and Argument Structure. Nanzan University, Nagoya: Research report for the Ministry of Education Grant-in-Aid for Scientific Research, 63-109.

Bosque I. (1996). "On Specificity and Adjective Position”, in J. Gutiérrez-Rexach \& L. Silva-Villar (eds) Perspectives on Spanish Linguistics. Volume 1. UCLA: Department of Linguistics, 1-13.

Calabrese A. (1993). "The Sentential Complementation of Salentino: A Study of a Language without Infinitival Clauses", in A. Belletti (ed.) Syntactic Theory and the Dialects of Italy. Turin: Rosenberg \& Sellier, 28-98.

Carballo Calero R. (1981). "Um exemplo de gerúndio flexional", in Problemas da língua galega. Lisbon: Sá da Costa, 129133.

Castellani A. (1969). "L'ancien poitevin et le problème linguistique des Serments de Strasbourg", Cultura Neolatina 29: 201-234.

Castellani A. (1973). I più antichi testi italiani. Edizione e commento. Bologna: Pàtron. 


\section{A. LEDGEWAY}

Chomsky, N. (1981). Lectures on Government and Binding. Dordrecht: Foris.

Chomsky N. (1986). Barriers. Cambridge Mass.: MIT Press.

Chomsky N. (1995). The Minimalist Program. Cambridge Mass.: MIT Press.

Cinque G. (1999). Adverbs and Functional Heads. A CrossLinguistic Perspective. Oxford: Oxford University Press.

Cinque G. (ed.) (2002). The Structure of DP and IP: The Cartography of Syntactic Structures, Volume 1. Oxford: Oxford University Press.

Cinque G. (2006). Restructuring and Functional Heads. The Cartography of Syntactic Structures. Volume 4. Oxford: Oxford University Press.

Cinque G. (2010). The Syntax of Adjectives. Cambridge, MA: MIT Press.

Cruschina S. (2012). Discourse-related Features and Functional Projections. Oxford \& New York: Oxford University Press

D'Alessandro R. (2010). "The Verbal Domain: TP-VP Structure \& Auxiliaries", in R. D'Alessandro, A. Ledgeway \& I. Roberts (eds) Syntactic Variation: The dialects of Italy. Cambridge: Cambridge University Press, 27-38.

D'Alessandro R. (2011). Agreement, Ergativity, Doubling and the Parametrization of Probes. Univeristy of Leiden: unpublished manuscript.

D'Alessandro R. \& Ledgeway A. (2010). "At the C-T Boundary: Investigating Abruzzese Complementation", Lingua 120: 2040-2060.

DeGraff M. (1997). "Verb Syntax in, and beyond, Creolization", in L. Haegeman (ed.) The New Comparative Syntax. London: Longman, 69-94.

Demonte V. (1995). "Dative alternation in Spanish", Probus 7: 5-30.

Demonte V. (1999). "A Minimal Account of Spanish Adjective Position and Interpretation", in J. Franco, A. Landa \& J. Martín (eds) Grammatical Analyses in Basque \& Romance 
Testing linguistic theory and variation to their limits

Linguistics. Papers in Honor of Mario Saltarelli. Amsterdam/ Philadelphia: Benjamins, 45-76.

Demonte V. \& Fernández-Soriano O. (2009). "Force and Finiteness in the Spanish Complementizer System", Probus 21: 23-50.

Dobrovie-Sorin C. (1994). The Syntax of Romanian. Berlin/ New York: Mouton de Gruyter.

Dupuis F. (1989). L'expression du sujet dans les subordonnées en ancien français. Université de Montréal: unpublished thesis.

Duranti A. \& Ochs E. (1979). "La pipa, la fumi? Un studio sulla dislocazione a sinistra nelle conversazioni”, Studi di grammatica italiana 8: 269-301.

Emonds J. (1978). “The Verbal Complex V'-V in French”, Linguistic Inquiry 9: 151-175.

Ewert A. (1935). "The Strasbourg Oaths", Transactions of the Philological Society 34: 16-35.

Fontana J. (1993). Phrase Structure \& the Syntax of Clitics in the History of Spanish. University of Pennsylvania: unpublished thesis.

Fontana J. (1997). "On the Integration of Second Position Phenomena", in A. van Kemenade \& N. Vincent (eds) Parameters of Morphosyntactic Change. Cambridge: Cambridge University Press, 207-249.

Giorgi A. (2009). "Toward a Syntax of the Subjunctive", in J. Quer (ed.) Twists of Mood: The Distribution and Interpretation of Indicative \& Subjunctive. Special Issue of Lingua 119.12: 1837-1858.

Giorgi A. (2010). About the Speaker. Towards a Syntax of Indexicality. Oxford: Oxford University Press.

Giorgi A. \& Longobardi G. (1991). The Syntax of Noun Phrases: Configuration, Parameters and Empty Categories. Cambridge: Cambridge University Press.

Giorgi A. \& Pianesi F. (1997). Tense and Aspect: From Semantics to Morphosyntax. Oxford: Oxford University Press. 


\section{A. LEDGEWAY}

Giorgi A. \& Pianesi F. (2004). "Complementizer Deletion in Italian", in L. Rizzi (ed.) The Syntax of CP and IP. Oxford: Oxford University Press, 190-210.

Giusti G. (2010). "Il sintagma aggettivale", in G. Salvi \& L. Renzi (eds) Grammatica dell'italiano antico (II volumi). Bologna: il Mulino, I, 593-616.

Gonzaga M. (2004). "The Structure of DP in European Portuguese - Evidence from Adjectives \& Possessives", Harvard Working Papers in Linguistics 10: 19-49.

Gupton T. (2010). The Syntax-Information Structure Interface: Subjects and Clausal Word Order in Galician. University of Iowa: unpublished thesis.

Haider H. (2001). "Parametrisierung in der Generativen Grammatik", in M. Haspelmath, E. König, W. Oesterreicher \& W. Raible (eds) Language Typology and Language Universals. An International Handbook. Volume I. Berlin: de Gruyter (= Handbücher zur Sprach- und Kommunikationswissenschaft, 20.1), 283-293.

Harder A. (1998). "La declinazione dei verbi in un dialetto di transizione nelle Marche", in G. Ruffino (ed.) Atti del XXI congresso internazionale di linguistica e filologia romanza. Centro di studi filologici e linguistici siciliani, Università di Palermo 18-24 settembre 1995. Volume V, sezione 5, Dialettologia, geolinguistica, sociolinguistica. Tübingen: Niemeyer, 389-399.

Hinzelin M.-O. (2009). "Neuter pronouns in Ibero-Romance: Discourse reference, expletives and beyond", in G. Kaiser \& E.-M. Remberger (eds) Null Subjects, Expletives \& Locatives in Romance. Konstanz: Konstanzer Arbeitspapiere des Fachbereichs Sprachwissenschaft (No. 123), 1-25.

Jones M. (1993). Sardinian Syntax. London: Routledge.

Joseph, J. (1992). "The Gascon Enunciative as [sic] Syntactic Solution", in C. Laeufer \& T. Morgan (eds) Theoretical Analyses in Romance Linguistics. Amsterdam/Philadelphia: Benjamins, 481-495. 
Testing linguistic theory and variation to their limits

Kaiser, G.A., M. Oliviéri \& K. Palasis. (in press). "Impersonal constructions in northern Occitan", in X.A. Álvarez Perez, E. Carrilho \& C. Magro (eds) Current Approaches to Limits and Areas in Dialectology. Cambridge: Cambridge Scholars Press/CSP.

Kayne R. (1984). Connectedness and Binary Branching. Dordrecht: Foris.

Lambrecht K. (1994). Information Structure and Sentence Form. Topic, Focus and the Mental Representations of Discourse Referents, Cambridge: Cambridge University Press.

Lapesa R. (1975). "La colocación del calificativo atributivo en español", in Homenaje a la memoria de Don Antonio Rodríguez-Moniño 1910-1970. Madrid: Castalia, 329-345.

Ledgeway A. (1998). "Variation in the Romance Infinitive: The Case of the Southern Calabrian Inflected Infinitive", Transactions of the Philological Society 96: 1-61.

Ledgeway A. (2000). A Comparative Syntax of the Dialects of Southern Italy: A Minimalist Approach. Oxford: Blackwell.

Ledgeway A. (2003). "Linguistic Theory and the Mysteries of Italian Dialects", in A. L. Lepschy \& A. Tosi (eds) Multilingualism in Italy: Past \& Present. Oxford: Legenda, 108140 .

Ledgeway A. (2004a). "Il sistema completivo dei dialetti meridionali: La doppia serie di complementatori", Rivista italiana di dialettologia 27: 89-147.

Ledgeway A. (2004b). "Extraordinary Agreement: The Case of the Ripano Verb", Italian Linguistics Round Table, St Catherine's College, University of Cambridge.

Ledgeway A. (2005). "Moving Through the Left Periphery: The Dual Complementiser System in the Dialects of Southern Italy", Transactions of the Philological Society 103: 336396.

Ledgeway A. (2006). "The Dual Complementiser System in Southern Italy: Spirito greco, materia romanza?", in A.L. Lepschy \& A. Tosi (eds) Rethinking Languages in Contact: The Case of Italian. Oxford: Legenda, 112-126. 


\section{A. LEDGEWAY}

Ledgeway A. (2007a). "La posizione dell'aggettivo nella storia del napoletano", in D. Bentley \& A. Ledgeway (eds) Sui dialetti italoromanzi. Saggi in onore di Nigel B. Vincent (The Italianist 27, Special supplement 1). Norfolk: Biddles, 104-125.

Ledgeway A. (2007b). "Old Neapolitan Word Order: Some Initial Observations", in A.L. Lepschy \& A. Tosi (eds) Histories and Dictionaries of the Languages of Italy. Ravenna: Longo, 121-149.

Ledgeway A. (2007c). "Diachrony and Finiteness: Subordination in the Dialects of Southern Italy", in I. Nikolaeva (ed.) Finiteness: Theoretical \& Empirical Foundations. Oxford: Oxford University Press, 335-365.

Ledgeway A. (2008). "Satisfying V2 in early Romance: Merge vs Move", Journal of Linguistics 44: 437-440.

Ledgeway A. (2009a). Grammatica diacronica del napoletano (Beihefte zur Zeitschrift für romanische Philologie Band 350). Tübingen: Niemeyer.

Ledgeway A. (2009b). "Aspetti della sintassi della periferia sinistra del cosentino", in D. Pescarini (ed.), Studi sui dialetti della Calabria (Quaderni di lavoro ASIt n.9). Padua: Unipress, 3-24.

Ledgeway A. (2010). "Subject Licensing in CP: The Neapolitan Double-Subject Construction", in P. Benincà \& N. Munaro (eds) Mapping the Left Periphery. The Cartography of Syntactic Structures, Volume 5. Oxford: Oxford University Press, 257-296.

Ledgeway A. (2012a). From Latin to Romance. Morphosyntactic Typology and Change. Oxford: Oxford University Press.

Ledgeway A. (2012b). "La sopravvivenza del sistema dei doppi complementatori nei dialetti meridionali", in P. Del Puente (ed.) Atti del II Convegno Internazionale di Dialettologia Progetto A.L.Ba. Rionero in Vulture: Calice Editore, 151176.

Ledgeway A. (in press). "Reconstructing Complementiser-drop in the Dialects of the Salento: A Syntactic or Phonological 
Testing linguistic theory and variation to their limits

Phenomenon?", in T. Biberauer \& G. Walkden (eds) Syntax Over Time: Lexical, Morphological, \& Information-structural Interactions. Oxford: Oxford University Press.

Ledgeway A. \& Lombardi A. (2005). "Verb Movement, Adverbs and Clitic Positions in Romance", Probus 17: 79-113.

Lemieux M. \& Dupuis F. (1995). "The Locus of Verb Movement in Non-asymmetric Verb-second Languages: The Case of Middle French", in A. Battye \& I. Roberts (eds) Clause Structure \& Language Change. Oxford: Oxford University Press, 80-109.

Lightfoot D. \& Hornstein N. (eds) (1994). Verb Movement. Cambridge: Cambridge University Press.

Lobo M. (2001). "On Gerund Clauses of Portuguese Dialects", in A. Veiga, V. M. Longa \& J. Anderson (eds.), El verbo. Entre el léxico y la gramática. Lugo: Tris Tram, 107-118.

Lois X. (1989). Aspects de la syntaxe de l'espagnol et théorie de la grammaire. Université de Paris VIII: unpublished thesis.

Lombardi A. (1997). The Grammar of Complementation in the Dialects of Calabria. University of Manchester: unpublished thesis.

Lombardi A. (1998). "Calabria greca e Calabria latina da Rohlfs ai giorni nostri: La sintassi dei verbi modali-aspettuali", in P. Ramat \& E. Roma (eds) Sintassi storica. Atti del XXX congresso internazionale della Società di linguistica italiana, Pavia, 26-28 settembre 1996. Rome: Bulzoni, 613-626.

Lombardi A. \& Middleton R. (2004). "Alcune osservazioni sull'ordine delle parole negli antichi volgari italiani”, in M. Dardano \& G. Frenguelli (eds) SintAnt. La sintassi dell'italiano antico. Atti del Convegno internazionale di studi. Rome: Aracne, 553-582.

Longa V. (1994). "The Galician Inflected Infinitive and the Theory of UG", Catalan Working Papers in Linguistics 4: 23-44.

López Alcaraz J. (1994). Los juramentos de Estrasburgo y La cantilena de Santa Eulalia. Comentario filológico de los dos primeros textos franceses. Murcia: Universidad de Murcia. 


\section{A. LEDGEWAY}

Loporcaro M. (1986). "L'infinito coniugato nell'Italia centromeridionale: Ipotesi genetica e ricostruzione storica", Italia dialettale 49: 609-665.

Lüdtke H. (1974). "Die Mundart von Ripatransone - ein sprachtypologisches Kuriosum", Acta Universitatis Carolinae Philologica 5: 173-177.

Lüdtke H. (1976). "La declinazione dei verbi in un dialetto di transizione marchigiano-abruzzese", Abruzzo 14: 79-84.

Mancini A. M. (1993). "Le caratteristiche morfosintattiche del dialetto di Ripatransone (AP), alla luce di nuove ricerche", in $\mathrm{S}$. Balducci (ed.) I dialetti delle Marche meridionali. Alessandria: Edizioni dell'Orso, 111-136.

Manzini M. R. \& Savoia L. (2005). I dialetti italiani e romanci. Morfosintassi generativa (3 vols). Alessandria: Edizioni dell'Orso.

Marchetti P. (1974). Le corse sans peine. Chennevières-surMarne: Assimil.

Maurer T. (1968). O infinito flexionado português. Estudo histórico-descritivo. São Paulo: Editora Nacional.

Mensching G. (2000). Infinitive Constructions with Specified Subjects. A Syntactic Analysis of the Romance Languages. Oxford: Oxford University Press.

Monachesi P. (2005). The Verbal Complex in Romance. A Case Study in Grammatical Interfaces. Oxford: Oxford University Press.

Motapanyane V. (2000). "The Generative Approach to Romanian Grammar. An Overview", in V. Motapanyane (ed), Comparative Studies in Romanian Syntax. Amsterdam: Elsevier, $1-48$.

Oliviéri M. (2009). "Syntactic Parameters \& Reconstruction", in G. Kaiser \& E.-M. Remberger (eds) Null Subjects, Expletives and Locatives in Romance. Konstanz: Konstanzer Arbeitspapiere des Fachbereichs Sprachwissenschaft 123: $27-46$. 
Testing linguistic theory and variation to their limits

Paoli S. (2002). "Il doppio 〈che〉 nei dialetti piemontesi", in G. Marcato (ed.) La dialettologia oltre il 2001. Padua: Unipress, 231-236.

Paoli S. (2003a). COMP and the Left-Periphery: Comparative Evidence from Romance. University of Manchester: unpublished thesis.

Paoli S. (2003b). "Mapping out the Left Periphery of the Clause: Evidence from North-Western Italian Varieties", in J. Quer, J. Schroten, M. Scorretti, P. Sleeman \& E. Verheugd (eds.), Romance Languages and Linguistic Theory 2001. Amsterdam/Philadelphia: Benjamins, 267-285.

Paoli S. (2005). "COMP: A Multi-talented Category. Evidence from Romance", in L. Brugè, G. Giusti, N. Munaro, W. Schweikert \& G. Turan (eds.), Contributions to the XXX Incontro di Grammatica Generativa. Venice: Cafoscarina, 185-202.

Parrino F. (1967). "Su alcune particolarità della coniugazione nel dialetto di Ripatransone", L'Italia dialettale 30: 156-166.

Poletto C. (2001). "Complementizer Deletion and Verb Movement in Standard Italian”, in G. Cinque \& G. Salvi (eds) Current Studies in Italian Syntax. Essays Offered to Lorenzo Renzi. Amsterdam: Elsevier, 265-286.

Pollock J.-Y. (1989). "Verb Movement, Universal Grammar, and the Structure of IP", Linguistic Inquiry 20: 365-424.

Pountain C. (1998). "Nuevo enfoque de la posición del adjetivo atributivo", in G. Ruffino (ed.) Atti del XXI congresso internazionale di linguistica e filologia romanza. Centro di studi filologici e linguistici siciliani, Università di Palermo 1824 settembre 1995. Volume II, sezione 2, Morfologia e sintassi delle lingue romanze. Tübingen: Niemeyer, 697-708.

Radatz H.-I. (2001). Die Semantik der Adjektivstellung. Tübingen: Niemeyer.

Reiner E. (1968). La place de l'adjectif épithète en français. Vienna \& Stuttgart: Wilhelm Braumüller.

Ribeiro I. (1995). "Evidence for a Verb-second Phase in Old Portuguese", in A. Battye \& I. Roberts (eds) Clause Structure 


\section{A. LEDGEWAY}

\& Language Change. Oxford: Oxford University Press, $110-139$

Richard L. (1988). "On the Double Object Construction", Linguistic Inquiry 19: 335-391.

Rizzi L. (1982). Issues in Italian Syntax. Dordrecht: Foris.

Rizzi L. (1986) "Null Objects in Italian \& the Theory of pro", Linguistic Inquiry 17: 501-557.

Rizzi L. (ed.) (2004). The Structure of CP and IP. The Cartography of Syntactic Structures. Volume 2. Oxford: Oxford University of Press.

Roberts I. (1985). "Agreement Parameters and the Development of English Modal Auxiliaries", Natural Language and Linguistic Theory 3: 21-58.

Roberts I. (1993). Verbs \& Diachronic Syntax. A Comparative History of English and French. Dordrecht: Kluwer.

Rohlfs G. (1969). Grammatica storica della lingua italiana e dei suoi dialetti. Sintassi e formazione delle parole. Turin: Einaudi.

Rohlfs G. (1970). Le gascon: Etude de philologie pyrénéenne. Tübingen: Niemeyer.

Rohrbacher B. (1997). Morphology-Driven Syntax. Amsterdam/ Philadelphia: Benjamins.

Salvi G. (2004). La formazione della struttura di frase romanza. Ordine delle parole e clitici dal latino alle lingue romanze antiche. Tübingen: Niemeyer.

Sandfeld K. \& Olsen H. (1960). Syntaxe roumaine. II. Les groupes de mots. Copenhagen: Munksgaard.

Sauzet P. (1989). "Topicalisation et prolepse en occitan", Revue des langues romanes 93: 235-273.

Schifano N. (2011). Verb-movement in Italian, French \& Spanish: A Survey from Written Sources. Universities of Cambridge/ Venice: unpublished thesis.

Schifano N. (in prep.) Romance Verb Movement. A Comparative Analysis. University of Cambridge: unpublished doctoral thesis. 
Testing linguistic theory and variation to their limits

Scorretti N. (1994). Complementizer Deletion. University of Amsterdam: Unpublished doctoral thesis.

Skårup P. (1975). Les premières zones de la proposition en ancien français. Copenhagen: Akademisk Forlag.

Sornicola R. (1996). "Alcune strutture con pronome espletivo nei dialetti italiani meridionali", in P. Benincà, G. Cinque, $\mathrm{T}$. De Mauro \& N. Vincent (eds) Italiano e dialetto nel tempo: Saggi di grammatica per Giulio C. Lepschy. Roma: Bulzoni, 323-340.

Sornicola R. (1997). "Campania”, in M. Maiden \& M. Parry (eds) The Dialects of Italy. London: Routledge, 330-337.

Tabachovitz A. (1932). Etude sur la langue de la version française des Serments de Strasbourg. Uppsala: Almqvist \& Wisksells Boktryckeri-A.-B.

Thiella A. (2008). "Il sintagma nominale negli antichi volgari di area veneta e lombarda", Laboratorio sulle varietà romanze antiche 2: 1-163.

Terzi A. (1994). "Clitic Climbing from Finite Clauses and Long Head Movement", Catalan Working Papers in Linguistics 3: 97-122.

Terzi A. (1996). "Clitic Climbing from Finite Clauses and Tense Raising”, Probus 8: 273-295.

Vance B. (1997). Syntactic Change in Medieval French. Verbsecond and Null Subjects. Dordrecht: Kluwer.

Vanelli L. (1980). "A Suppletive Form of the Italian Article and its Phonosyntax", Journal of Linguistic Research 1: 69-90.

Vanelli L. (1986). "Strutture tematiche in italiano antico", in H. Stammerjohann (ed.) Tema-Rema in Italian. Tübingen: Narr, 248-273.

Vanelli L. (1999). "Ordine delle parole e articolazione pragmatica nell'italiano antico: La < prominenza > pragmatica della prima posizione nella frase", Medioevo romanzo 23: 229246.

Vanelli L., Renzi L. \& Benincà P. (1985). "Typologie des pronoms sujets dans les langues romanes", in Actes $d u$ XVII congrès international de linguistique et philologie 


\section{A. LEDGEWAY}

romanes. Volume 3: Linguistique descriptive, phonétique, morphologie et lexique. Aix-en-Provence: Université de Provence, 163-176.

Vikner S. (1997). "V-to-I Movement and Inflection for Person in all Tenses", in L. Haegeman (ed.) The New Comparative Syntax. London: Longman, 189-213.

Villa-García J. (2010). Recomplementation and Locality of Movement in Spanish. University of Connecticut: unpublished second general examination paper.

Vincent N. (1986). "La posizione dell'aggettivo in italiano", in H. Stammerjohann (ed.) Tema-rema in italiano - ThemeRheme in Italia-Thema-Rhema in Italienischen. Tübingen: Narr, 181-195.

Vincent N. (1996). "L'infinito flesso in un testo napoletano del Trecento", in P. Benincà, G. Cinque, T. De Mauro \& N. Vincent (eds) Italiano e dialetto nel tempo: Saggi di grammatica per Giulio C. Lepschy. Roma: Bulzoni, 389409.

Vincent N. (1998). "On the Grammar of Inflected Non-finite Forms (with Special Reference to Old Neapolitan)", in I. Korzen \& M. Herslund (eds) Clause Combining and Text Structure. Copenhagen Studies in Language 22: 135-158.

Vincent N. (2006). "Il problema del doppio complementatore nei primi volgari d'Italia", in A. Andreose \& N. Penello (eds) Laboratorio sulle varietà romanze antiche: Giornata di lavoro sulle varietà romanze antiche. Padua: University of Padua, 27-42.

Vincent N. (2007). "Learned vs Popular Syntax: Adjective Placement in Early Italian Vernaculars", in A.L. Lepschy $\&$ A. Tosi (eds) Histories and Dictionaries of the Languages of Italy. Ravenna: Longo, 55-75.

Wanner D. (1981). "Surface Complementizer Deletion: Italian che $\sim$ Ø”, Journal of Italian Linguistics 6: 47-82.

Wanner D. (1998). "Les subordonnées à double complémentateur en roman médiéval", in G. Ruffino (ed.) Atti del XXI congresso internazionale di linguistica e filologia romanza. 
Testing linguistic theory and variation to their limits

Centro di studi filologici e linguistici siciliani, Università di Palermo 18-24 settembre 1995. Volume I, sezione 1, Grammatica storica delle lingue romanze. Tübingen: Niemeyer, 421-433.

Wheeler M. (1988). “Occitan”, in M. Harris \& N. Vincent (eds) The Romance Languages. London: Routledge, 246-278. 